\title{
The tensions of defining and developing thought leadership within knowledge-intensive firms
}

\section{William S. Harvey, Vince-Wayne Mitchell, Alessandra Almeida Jones and Eric Knight}

\begin{abstract}
Purpose - A major part of knowledge management for knowledge-intensive firms such as professional service firms is the increasing focus on thought leadership. Despite being a well-known term, it is poorly defined and analysed in the academic and practitioner literature. The aim of this article is to answer three questions. First, what is thought leadership? Second, what tensions exist when seeking to create thought leadership in knowledge-based organisations? Third, what further research is needed about thought leadership? The authors call for cross-disciplinary and academic-practitioner approaches to understanding the field of thought leadership.

Design/methodology/approach - The authors review the academic and practitioner literature on thought leadership to provide a rich oversight of how it is defined and can be understood by separating inputs, creation processes and outcomes. The authors also draw on qualitative data from $12 \mathrm{in}$-depth interviews with senior leaders of professional service firms.

Findings - Through analysing and building on previous understandings of the concept, the authors redefine thought leadership as follows: "Knowledge from a trusted, eminent and authoritative source that is actionable and provides valuable solutions for stakeholders". The authors find and explore nine tensions that developing thought leadership creates and propose a framework for understanding how to engage with thought leadership at the industry/macro, organisational/meso and individual/micro levels. The authors propose a research agenda based on testing propositions derived from new theories to explain thought leadership, including leadership, reducing risk, signalling quality and managing social networks, as well as examining the suggested ways to resolve different tensions.

Originality/value - To the best of the authors' knowledge, they are the first to separate out thought leadership from its inputs, creation processes and outcomes. The authors show new organisational paradoxes within thought leadership and show how they can play out at different levels of analysis when implementing a thought leadership strategy. This work on thought leadership is set in a relatively underexplored context for knowledge management researchers, namely, knowledge-intensive professional service firms.
\end{abstract}

Keywords Professional service firms, Tensions, Thought leadership, Definitions, Expert knowledge, Knowledge-intensive firms

Paper type Research paper

\section{Introduction}

Thought leadership is a well-known and yet, surprisingly, a poorly understood concept. It has attracted growing attention from certain knowledge-intensive firms, namely, professional service firms (PSFs) who are creating large volumes of practitioner material distributed through magazines, white papers, blogs, podcasts and videos. As demand grows, $69 \%$ of these organisations have a specific head of thought leadership. Indeed, one survey of 1,200 US businesses reveals that not only are decision-makers spending more time reading thought leadership year-on-year, but it plays an important part in vetting organisations and generating opportunities with existing and new clients (Edelman, 2019).
William S. Harvey is

Professor of Management and Associate Dean at the University of Exeter

Business School, Exeter, UK. Vince-Wayne Mitchell is Professor of Marketing and Head of Discipline at the University of Sydney Business School, Sydney, Australia. Alessandra Almeida Jones is Director of Marketing at Baker McKenzie, London, UK. Eric Knight is Professor of Strategic Management and Executive Dean at Macquarie Business School, Sydney, Australia.

Received 12 June 2020 Revised 3 September 2020 Accepted 14 September 2020

(C) William S. Harvey, Vince-Wayne Mitchell, Alessandra Almeida Jones and Eric Knight. Published by Emerald Publishing Limited. This article is published under the Creative Commons Attribution (CC BY 4.0) license. Anyone may

reproduce, distribute, translate and create derivative works of this article (for both commercial and non-commercial purposes), subject to full attribution to the original publication and authors. The full terms of this license may be seen at http://creativecommons.org/licences/by/4.0/ legalcode 
While individual thought leaders are in plentiful supply, many organisations struggle to establish their thought leadership approach (Alexander and Badings, 2012). Some suggest clients are literally drowning in content and far too much of it fails to connect (Leavitt et al., 2016). Others suggest that many organisations are squandering time, money and effort on initiatives that do not move the needle in terms of establishing a differentiated brand identity, deep trust and loyal followership (Alexander and Badings, 2012). As we will show, the diffuse nature of thought leadership is complicated by the interplay between the individual, the organisation and the industry context in which it occurs. Problems such as producing thought leadership is supposedly rare and unique, yet the sheer demand for thought leadership puts pressure on people and organisations to find ways of delivering quantity at the expense of quality. In addition, organisations face the challenge of spending significant time and financial resource on thought leadership that may have little measurable outcome or impact. Hence, it is not surprising that some scholars and practitioners consider it as yet another management fad (Hall, 2019; Kellaway, 2007; Spicer, 2017).

Knowledge-based organisations (KBOs) are a rich context in which to study thought leadership. PSFs are particularly important from a knowledge management perspective for thought leadership for several reasons. First, professionals themselves contain the knowledge from which they generate revenue so their knowledge is highly distributed throughout the organisation; a phenomenon which is exaggerated by their partnership structure. This distributes power within the firm and means organisational knowledge management systems can face partner resistance if they significantly undermine the power of partners. Second, partly because of the individual nature of the knowledge and partly because much of the added value of knowledge is tacit, there is little formal organisational knowledge repository and few tangible ways to manifest and share their expertise. This is unlike other KBOs, for example engineering, IT and software development or pharmaceuticals, which have products which act as signals of quality, or sector relevance and importance. The knowledge-intensive nature of PSFs lends itself to opaque quality where quality is difficult for non-experts to evaluate (Harvey et al., 2017), meaning firms need to signal quality in alternative ways such as through reputation (von Nordenflycht, 2010), or as we suggest, through the medium of thought leadership. Third, because of the unique nature of client needs which require new solutions to be created each time and service heterogeneity of individuals applying that knowledge, it is less easy to have standardisation of knowledge practices and readily accessible inventories of knowledge. As a result and as a context in which to explore knowledge management, thought leadership becomes more important and relevant for these types of firms where differences in the nature of knowledge, jurisdictional control and client relationships have implications on their organisational form (Malhotra and Morris, 2009).

Because thought leadership is about developing and disseminating knowledge, how this increasingly prevalent form of knowledge management occurs is relevant for knowledge management scholars. Recent work in the management literature has started to explore how thought leadership can help leaders become more effective (Kerns, 2019). However, the challenges consultants face when trying to be management thought leaders (Wright, 2019), as well as the implications of thought leadership in social media on improving approaches to marketing, brand performance and customer relationships (Magno and Cassia, 2019), has largely been ignored by knowledge management scholars and related work on knowledge dissemination (Bertoldi et al., 2018; Flynn et al., 1996; Nguyen et al., 2019; Le and Lei, 2019; Bican et al., 2017; Ashok et al., 2016; Wu and Hu, 2018; Nguyen et al., 2019; Gardner, 2015), including within the special issue in the Journal of Knowledge Management on KBOs (Millar et al., 2016). Moreover, little work has focused on PSFs within KBOs. Surprisingly, the knowledge management literature has ignored the concept and phenomenon of thought leadership, which is a problem because if thought leadership is poorly understood, it is not likely to be managed effectively. 
We approached the topic of thought leadership inductively and asked the following research questions. First, what is thought leadership? Second, what tensions exist when seeking to create thought leadership in KBOs? Third, what further research is needed on thought leadership? In responding to these questions, we contribute to the knowledge management literature in several ways. First, to understand thought leadership better, we examine how it applies to a hitherto under-researched sector of KBOs, namely, PSFs which are a rich context for delineating the problems of developing thought leadership. Second, we enhance the definition of thought leadership based on a systematic review, and highlight its inputs, processes and outcomes. This provides greater clarity around the thought leadership concept by explaining what it is and what it is not, and we provide a convenient framework for other knowledge management scholars to use. Third, as thought leadership is a form of creative intellectual property innovation, we draw on the notion of paradoxical frames for creative and innovation outputs (Andriopoulos and Lewis, 2009; Calic et al., 2019), to examine the tensions and paradoxes involved in creating thought leadership. Our industry-level analysis adds to this literature which has previously focused on organisations and individuals, and identifies a different set of paradoxes. Fourth, previous work in understanding knowledge management in KBOs has identified several useful theories, including psychological ownership and procedural and interactive justice, territoriality (Huo et al., 2016), social media theory (Grant, 2016), trust, connectivity and interaction issues (Khvatova et al., 2016), spatial/temporal/configurational dispersion and information processing theory (Chen and Lin, 2016), team absorptive capacity (Lowik et al., 2016) and social capital theory (Magno and Cassia, 2019). We add further theoretical richness from perceived risk theory, signalling theory, social network theory and leadership theories. Fifth, we propose practical ideas for how practitioners can cope with these tensions through living with the paradox, trading-off options and finding compromising solutions as well as showing how key criteria, for example originality, reach and audience type, frequency and marketing objectives, could be used for assessing thought leadership at different levels: the individual, organisational and industry level. Finally, we present a future practitioner and academic research agenda which explores practical considerations and theoretical propositions to motivate both cross-disciplinary and academic-practitioner understandings of thought leadership.

We begin by providing a brief review of the relevant literatures in knowledge management and KBO and thought leadership before systematically analysing the current definitions of thought leadership and explaining our methodology which enabled us to identify the problems, paradoxes and tensions involved in creating thought leadership. With these in mind, we then move to discussing theories to explain thought leadership before finally setting out a wide agenda for further research. We now outline three areas of literature on which we build, namely, knowledge management in KBOs, thought leadership and organisational paradoxes.

\section{Literature review}

\section{Knowledge-based organisations and knowledge management}

$\mathrm{KBOs}$ depend on disseminating knowledge to clients as their primary business. Prior literature has examined a diverse array of $\mathrm{KBOs}$, including contexts which are clearly knowledge-intensive environments such as research and development (R\&D) teams (Huo et al., 2016), referral mental hospitals (Rohajawati et al., 2016) and information technology service firms (Ashok et al., 2016), as well as contexts where the knowledge intensity is less obvious such as an international company's financial centre (Khvatova et al., 2016), home insurance firms (Grant, 2016), medium-tech firms (Lowik et al., 2016) and an electronics company (Kwon and Cho, 2016). A wider survey has included product design, engineering services, finance and accounting, human resource, IT, knowledge services, legal services, marketing and sales, R\&D and software development (Chen and Lin, 2016). Some work has 
even looked at the educational field as examples of KBOs such as nanotechnology and social science research (Zalewska-Kurek, 2016), universities, research institutes (Huo et al., 2016), a business school (Marin et al., 2016) and secondary schools (Chu, 2016).

Within this work, a range of different knowledge management issues have attracted attention. One set of issues has focused on knowledge management within the organisation, such as process-competency requirements within knowledge-intensive processes (Little and Deokar, 2016), how to measure trust as a receptivity force in an intraorganisational knowledge-sharing network (Khvatova et al., 2016), a strategic approach for making trade-offs between knowledge and risk (Coleman and Casselman, 2016) and knowledge management strategies for a mental health organisation (Rohajawati et al., 2016). Further research has explored the relationship between transactive memory systems and organisational innovation (Kwon and Cho, 2016), organisational design of offshoring service organisations using an information processing perspective which incorporates the factors of collaborative information technologies, task commoditisation and global customer service delivery (Chen and Lin, 2016).

A second collection of studies has examined the role of individuals in knowledge management. This includes work on why employees hide knowledge and the negative effects of this activity (Huo et al., 2016), and the use of social media tools for the purposes of knowledge and information sharing across a supply chain in the UK home insurance market (Grant, 2016). This body of work has also examined the actions autonomous knowledge workers perform to implement formalised knowledge strategies as part of an accreditation process (Marin et al., 2016); how knowledge workers' improvisation processes promote both knowledge transfer and protection in knowledge-intensive organisations through four specific knowledge transfer mechanisms - an experimental culture, minimal structures, the practice of storytelling and shared mental models, (Krylova et al., 2016); and how collaboration with different types of users and investments in knowledge management practices affect radical versus incremental process innovation differently (Ashok et al., 2016). In addition, there has been further work on how knowledgeintensive teams can develop and enhance their team absorptive capacity (ACAP) level by exploring whether individual and organisational factors are complements or substitutes for team ACAP (Lowik et al., 2016), the influence of a principal's leadership for spearheading knowledge management in secondary schools (Chu, 2016) and the strategic behaviours of researchers when producing knowledge in nanotechnology and the social sciences (Zalewska-Kurek, 2016).

In summary, the work on $\mathrm{KBO}$ s has focused on knowledge management issues related to both dynamics within and beyond the organisation. In doing so, it has tended to focus on management from the perspective of resolving particular problems. Knowledge management is presented as something that can be measured, defined and transferred, placing emphasis on the defined parameters of knowledge. Notwithstanding the prevailing view of knowledge management, less attention has been given to the more projective and speculative nature of knowledge creation within KBOs. This is particularly pertinent in the case of thought leadership, which is the process by which KBOs develop knowledge of outward influence.

\section{Thought leadership}

The term thought leadership became popularised after Joel Kurtman (1998) published his influential book: Thought Leaders: Insights on the Future of Business, which included contributions from 12 practitioners and academic gurus aiming to make a revolutionary contribution to management philosophy. Although sometimes referred to as opinion leadership (Flynn et al., 1996), which is defined by Rogers and Cartano (1962, p. 435) as people who exert significant influence over the decision of others, thought leadership is a form of opinion leadership which involves aspects of novelty and expertise. Some work 
focuses on greater customer engagement and collaboration throughout the entire research and development process, but especially in the early stages of thought leadership development (Leavitt et al., 2016). Others have focused on how "thought leadership" and "content marketing" are different (Bailyn, 2019) and how research-based strategies can strengthen expertise-driven brands (Frederiksen and Tyreman, 2018). But many provide practitioner guidelines for effective thought leadership such as not to sell anything except ideas and focus on one thing at a time (Rasmus, 2012), or focus on developing deep expertise (Prince and Rogers, 2012) and emphasise on helping others and taking risks (McKeon, 2009). However, much of this work is from practitioners and is opinion- and experience-based, as opposed to being grounded in research (McCrimmon, 2005).

For this reason, the role of thought leadership in knowledge management has largely been overlooked. This is problematic for both empirical and theoretical reasons. Empirically, thought leadership occupies a significant amount of time, resource and effort among KBOs, especially in the professional service domain such as law, accounting and management consulting firms. Yet there are few studies of thought leadership in these context. Theoretically, the absence of a study of thought leadership is problematic because it means that the more speculative and tension-fuelled aspects of knowledge management are under-examined.

Indeed, discussion around knowledge dissemination concepts, including that in the Journal of Knowledge Management, has focused on the individual; for example, knowledge leaders (Bertoldi et al., 2018), opinion leaders (Flynn et al., 1996) and multiple levels (Nguyen et al., 2019) such as determinants of innovation capability (Le and Lei, 2019), open innovation (Bican et al., 2017), knowledge management and innovation (Ashok et al., 2016; Wu and $\mathrm{Hu}, 2018)$. However, the tensions across these levels has not attracted much attention. Yet it is the ability to integrate knowledge across these levels that is so crucial to thought leadership. Thought leadership requires the ability to go beyond a single context to understand the integrative components of knowledge both within and beyond a single organisation. Moreover, it often touches on topics that are inherently messy, tension-fuelled and evade resolution. This is the reason why leadership of thought, as opposed to management, is so important. This, then gives grounds for thought leadership being an important theoretic concept for attention by scholars of knowledge management.

\section{Organisational paradoxes}

To aid consideration of how knowledge might be understood in such tension-fuelled contexts, we draw on a lens offered by organisational paradox scholarship which has identified tension as a strategic mechanism in management (Hahn and Knight, 2019). Organisational paradoxes "denote persistent contradictions between interdependent elements" (Schad et al., 2016, p. 6) in organisational life. Often such contradictions are opposing elements that "seem logical individually but inconsistent and even absurd when juxtaposed" (Smith and Lewis, 2011, p. 382). However, these opposing elements are frequently interdependent and linked to each other (Smith and Lewis, 2011). Moreover, much of the paradox literature agrees that paradoxes must be persistent over time (Cunha and Clegg, 2018). Organisational paradoxes are, therefore, persistent contradictions between interdependent elements and where inherent material factors and socially constructed meaning co-constitute paradox (Hahn and Knight, 2019).

Although we do not seek to contribute to the paradox literature, we use it as a lens to explore how thought leadership is created and managed. In addition, we draw on the organisational tensions and paradox literature to present our findings and framework. This follows the work of others who have used paradox as a lens to explore contributions beyond paradox theory, such as in the areas of corporate sustainability (Ivory and Brooks, 2018), sustainability and identity (Carollo, and Guerci, 2018), exporter behaviour (Vendrell-Herrero et al., 2019), paradoxical leader behaviour in long-term corporate development (Zhang and Han, 2019), 
creativity from paradoxical experiences (Calic et al., 2019) and social enterprises (Hahn and Knight, 2019). We now seek to follow a similar path for knowledge management and the role of thought leadership therein.

Having set out our primary literature ideas and approach, we now provide details on the methodology we deployed to analyse the thought leadership research, and how we defined a novel perspective for conceptualising thought leadership and identify the tensions of generating it within PSFs.

\section{Methodology}

The research objectives of this paper were explored through two principle sources of data collection. First, from an extensive literature review of over 50 academic and professional articles (Baumeister and Leary, 1997; Wong et al., 2013), we focused on re-defining thought leadership through an analysis of the definitions offered. Literature sources were found using Google Scholar searches, using the search terms of "thought leadership", "management gurus" and "thought leaders".

Second, the aim of the empirical study was to explore the organisational and individual issues involved in PSFs engaging in thought leadership. As researching organisational paradoxes relies on complexity thinking, it does not lend itself to positivist research approaches (Lewis, 2000). Based on the unexplored nature of the phenomenon and the limited secondary data, we adopted a qualitative research design and inductive research approach, and used in-depth interviews. As a result, our second principle source of data collection was 12 in-depth open-ended interviews with leading in-house practitioners and consultants.

\section{Sample}

We used a purposive sampling approach according to a range of firm sizes, sectors and specialist knowledge (Miles and Huberman, 1994). For the study, 12 organisations representing different sized firms in various sectors (law, management consultancy, accounting, finance and thought leadership consultancies) were chosen to examine any differences in approaches to thought leadership. All organisations were well established in their industries and have demonstrated the ability to deploy thought leadership over time. These participants were from a variety of large or medium-sized PSFs in London. Furthermore, these PSFs were involved in a variety of thought leadership operations and have dedicated teams and units to understand and execute the topic. The majority of the firms were categorised as medium-size firms with more than 50 staff (see Table 1). In addition, through an initial review of the organisational activities, we

\section{Table 1 Interviewee profiles}

\begin{tabular}{|c|c|c|c|c|c|}
\hline & Sector & No.of employees & Position & Years of experience & Gender \\
\hline 1 & Legal & 2,800 & Partner in charge of TL & 15 & Male \\
\hline 2 & Legal & 5,000 & Head of campaigns & 15 & Female \\
\hline 3 & Legal & 3,000 & Head of Marketing and Communications & 18 & Male \\
\hline 4 & Accountancy & 260,000 & Head of Marketing & 22 & Female \\
\hline 5 & Accountancy & 276,000 & Head of UK Markets & 15 & Female \\
\hline 6 & Accountancy & 56,000 & Senior Manager & 11 & Male \\
\hline 7 & Property & 14,000 & Head of Marketing & 18 & Male \\
\hline 8 & Architecture & 6,000 & Partner & 28 & Female \\
\hline 9 & Architecture & 500 & Partner & 23 & Female \\
\hline 10 & Consulting & 27,000 & Head of Communications & 25 & Female \\
\hline 11 & Consulting & 513,000 & Partner & 22 & Female \\
\hline 12 & Consulting & 25,000 & Director of Marketing & 30 & Male \\
\hline
\end{tabular}


noted that each organisation provided differing levels of thought leadership which provided varying perspectives on their approach to thought leadership initiatives. With each organisation demonstrating different perspectives on their thought leadership strategies, this presented a rich and diverse data collection context. Thus, studying different types of PSFs provided an opportunity to develop a more generalised set of tensions.

As gaining access and interviewing senior professionals is difficult to achieve, we adopted a key informant methodology for interviewing elite professionals (Mitchell, 1994; Harvey, 2011) which allows such interviewees to tap into a wider knowledge base within their organisations than other interviewees. This is useful when respondents have high interest in the study, complete and specialised knowledge and high ranking positions in the organisation (Mitchell, 1994). The focus of the study was to select the people who were working on thought leadership issues for large PSFs. Participants had worked for their organisations for multiple years which was important given the length of time needed to acquire knowledge to generate thought leadership activity. We used three criteria for participant selection. First, the participants were senior PSF managers of thought leadership or experts advising on thought leadership for PSFs. Second, they had at least 15 years of experience, either managing thought leadership activity or running a consultancy specialising in advising on it. Third, they had relevant knowledge of thought leadership as it applies to PSFs and were involved both directly and indirectly with it.

The research focused on interviews with 12 participants from 12 different organisations. Participants were in full-time employment, were typically head of thought leadership or partners with thought leadership responsibilities and with an age range of between 40 and 61. As such, participants demonstrated significant levels of experience and relevant background (see Table 1 for a summary of the interviewee profiles).

Interviewees were selected first through personal contact points of the research team and using the snowball technique to gain access to more participants from those contact points. The expertise and professional experience of these participants were already known to the research team and deemed appropriate for the current study. Second, the relevant and potential participants were also identified through Linkedln using advanced search tools, for example using key words such as "Head of Thought Leadership", and by searching through different communities on Linkedln. Those who agreed to participate in the study were informed of the purpose of the research and their consent was obtained prior to being interviewed. Third, convenience played a minor role in the selection process, providing some ease in gaining access and agreement from these elite participants (Harvey, 2011).

\section{Data collection}

The 12 interviews were conducted through a semi-structured format to allow for both static and dynamic questioning. The questions used were designed to generate qualitative data on the issues of thought leadership definition; challenges in creating and implementing thought leadership activities; the people and organisational problems in developing thought leadership; and measurement concerns about its effectiveness. A semi-structured format was used to provide a consistent structure for each interview, which was developed to allow flexibility in the questions as needed, based on participant responses.

The interview questions were sent to the participants in advance and the interviews were conducted face-to-face or over the telephone. The interviews lasted for around $50 \mathrm{~min}$ on average and ranged from 40 to $120 \mathrm{~min}$. Interviews were recorded for reference and for transcription and coding purposes. Data were collected over a one-year period and all interviews were fully recorded using a digital voice recorder. In addition, detailed notes were taken during each interview to capture notable points for follow-up questions. Following the analysis of the interview transcripts and notes, several individuals were selected for follow-up discussions to clarify and validate their responses. 


\section{Data analysis}

A grounded theory approach to data analysis (Hussein et al., 2014) seeks to explain and interpret the connections within the phenomenon. In our case, it was helpful because of its dynamic approach to theory development, which is suitable for relatively new perspectives on a research agenda (Suddaby, 2006) such as thought leadership. We assume that individuals within the firms are actively constructing the reality in which they work because thought leadership is relatively new and burgeoning (Isabella, 1990). Thought leadership is also under-researched and under-theorised, and thus grounded theory helped us to develop a framework based on the data analysis rather than testing previous theories or hypotheses. This inductive approach to detecting themes enabled us as researchers to code the data "without trying to fit it into a pre-existing coding frame or the researcher's analytic preconceptions" (Braun and Clarke, 2006, p. 83). This ensured that themes arose from the data and that there were no prior assumptions regarding the number and types of themes in the data.

Traditional approaches to grounded theory suggest that no a priori knowledge should be obtained through a literature review or the development of research questions to avoid any preconceived ideas of the phenomenon. However, for this study, a basic review of literature was conducted to provide an understanding of prior knowledge management and KBO research contributions and gaps in framing the boundaries of the study, but not used to build a theoretical framework other than the use of organisational paradoxes. The adoption of the levels of analysis - micro, meso and macro - came from the interviews and secondary data as a way of structuring the kinds of thought leadership that were identified from the literature and interviews.

The interviews provided rich primary data to learn about the expert key informants' perceptions, concerns, observations and reactions to thought leadership within PSFs in general and within their organisations. The interviews and data analysis were performed simultaneously. After each interview, the data were transcribed and analysed line-by-line from the transcribed interview (Friese, 2014). As each interview was completed and transcribed, data analysis involved initial coding of issues and problems, which provided an understanding of the organisational and individual environment. Based on the analysis of these codes, subsequent interviews were conducted to address specific areas that required further investigation. Comparing and matching codes helped us to determine the main themes that could provide detailed explanations of the problems involved in thought leadership creation (Hussein et al., 2014) (e.g. thought leadership effectiveness measures, challenges of getting enough thought leadership, the substantive nature of thought leadership). During the second coding round, the common themes emerged from the 12 respondents and the themes were organised according to the trade-offs or tensions. The tensions were something that typically at least six interviewees mentioned at least once.

Codes were compared to explore common responses which offered some benefits in understanding the underlying context and to prevent any mistakes or misinterpretations (Howitt and Cramer, 2010). To mitigate the possibility of human errors and bias, peer review and member checks were performed to improve the validity and credibility of the findings. Peer review involved asking colleagues to review and discuss the results and then provide feedback on the interpretations generated from the data. Member checks consisted of bringing the researcher and participants together to confirm the mutual understanding and interpretation of the data. Through subjective interpretation, data were analysed to build an understanding of the phenomena within the context of the study (Carroll and Swatman, 2000). The underlying objective behind the approach was the development of a framework to organise the data and aid interpretation of thought leadership within PSFs. 


\section{Results}

\section{Revisiting thought leadership}

To date, the evidence around defining thought leadership has been mostly anecdotal and opinion led, stemming largely from practitioner literature (Brenner, 2019; Crestodina, 2020; Manbitesdog, 2014). To add more academic rigour, we collected different definitions of thought leadership based on paraphrasing definitions from multiple sources (see Table 2).

Table 2 illustrates the disparate understandings of thought leadership within the existing academic and practitioner literature. The divergence of definitions of thought leadership is problematic as it means that multiple concepts are in play. Moreover, some definitions explicitly mention what thought leadership is not, namely, related to products, services or lead generation. A survey of 481 marketers by Orbit Media Studios (2020), in partnership with Mantis Research and SurveyMonkey Audience, highlights that a variety of definitions also prevail among practitioners. The authors combined the most common answers from the thought leadership survey (those with $65 \%$ agreement) into a single definition for thought leadership content:

Educational content, produced by an expert or business, that identifies new trends and is supported by research. It challenges the thinking of the target audience and drives marketing outcomes (Orbit Media Studios, 2020, np).

Unfortunately, the above definition only serves to highlight two problems we suggest are conflated with thought leadership, namely, inputs, processes and outcomes, and combining different levels of analysis.

We argue that many definitions mix up the level of analysis because thought leadership can be applied to activities at the industry, organisational or individual level. Table 2 shows that outcomes, as opposed to inputs and process, dominate previous definitions. It also highlights the key role of thought leadership at all levels is to create outcomes, which we return to later when discussing measurement. Surprisingly, process, which is the main focus of our empirical work, is sparsely mentioned in the thought leadership literature. This approach is consistent with recent work which has made a distinction between thought leadership as a capability (i.e. thought leadership competence as an input) and thought leadership as an outcome (i.e. trusted authority recognition as an outcome) (Barry and Gironda, 2017). What we observe from a level of analysis viewpoint is that individual-level definitions tend to emphasise expertise and influence; organisationa/-level definitions tend to focus on organisational issues such as differentiation, brand and reputation building, stakeholders and relationship building; and industry-level definitions tend to focus on originality, big questions and education.

We find that many definitions of thought leadership conflate whether it is an input (the resources and conditions required to develop it), a process (the mechanisms through which it can be created and shared) or an outcome (the final form it takes and its effect on end users). For example, some mention the consequences or outcomes of thought leadership such as playing a key role in the development and deepening of relationships and increasing trust or driving change [see Bertoldi et al.'s (2018) work on the ability of knowledge leaders to change organisational environments] within an industry or society.

Through analysing the different definitions of thought leadership and separating them out according to inputs, processes and outcomes, we provide more precision (see Figure 1). For example, from interrogating the literature, we find that inputs to thought leadership are expertise, research-led, stakeholders, creation of ideas, insightful ideas, creation and expertise. This creates the groundwork for excellent content (e.g. positioning an organisation as a leader through producing insightful content) (Bailyn, 2019). Processes include dissemination, sharing knowledge and building relationships. Such processes involve presenting content that is salient to stakeholders (Velamuri et al., 2017), which may 
Table 2 Conceptual delineations of definitions of thought leadership from the academic and practitioner literature

\begin{tabular}{|c|c|c|c|c|c|}
\hline Abridged definition & Key themes & Scale of analysis & Input & Process & Outcome \\
\hline $\begin{array}{l}\text { Informed opinion leaders and the go-to } \\
\text { people in their field. Trusted sources } \\
\text { who move and inspire people with } \\
\text { innovative ideas and turn ideas into } \\
\text { reality (Brousseau, 2013) }\end{array}$ & $\begin{array}{l}\text { Opinion leaders } \\
\text { Trusted source } \\
\text { Influence } \\
\text { Actionable }\end{array}$ & Individual & $\begin{array}{l}\text { Trusted source } \\
\text { Opinion leaders }\end{array}$ & & $\begin{array}{l}\text { Influence } \\
\text { Actionable }\end{array}$ \\
\hline $\begin{array}{l}\text { Recognised experts in their field. The } \\
\text { go-to people to get results (Levy, 2014) }\end{array}$ & $\begin{array}{l}\text { Expertise } \\
\text { Results }\end{array}$ & Individual & Expertise & & Results \\
\hline $\begin{array}{l}\text { People who exert significant influence } \\
\text { on the decision of others (Rogers and } \\
\text { Cartano, 1962) }\end{array}$ & $\begin{array}{l}\text { Influence } \\
\text { Decisions }\end{array}$ & Individual & & & $\begin{array}{l}\text { Influence } \\
\text { Decisions }\end{array}$ \\
\hline $\begin{array}{l}\text { Pioneer new ideas rather then follow } \\
\text { conventional wisdom. Influence their } \\
\text { areas of expertise and generate } \\
\text { revenue and value for themselves and } \\
\text { their organisations (Tech Target, 2018) }\end{array}$ & $\begin{array}{l}\text { Influence } \\
\text { Expertise } \\
\text { Originality } \\
\text { Revenue }\end{array}$ & $\begin{array}{l}\text { Individual/ } \\
\text { organisational }\end{array}$ & Expertise & & $\begin{array}{l}\text { Influence } \\
\text { Revenue } \\
\text { Originality }\end{array}$ \\
\hline $\begin{array}{l}\text { Four content and character attributes: } \\
\text { new ideas, advancing ideas to provoke } \\
\text { new mindsets, an ability to lead and the } \\
\text { capacity to continually enlighten } \\
\text { audiences (Barry and Gironda, 2019) }\end{array}$ & $\begin{array}{l}\text { Future insights } \\
\text { Original ideas } \\
\text { Trusted authority } \\
\text { Gaining attention }\end{array}$ & $\begin{array}{l}\text { Individual/ } \\
\text { organisational }\end{array}$ & $\begin{array}{l}\text { New ideas } \\
\text { Trusted } \\
\text { authority }\end{array}$ & Leading & $\begin{array}{l}\text { Actionable } \\
\text { strategies } \\
\text { Business } \\
\text { solutions }\end{array}$ \\
\hline $\begin{array}{l}\text { Creation of ideas that lead to } \\
\text { advantages for businesses (Young, } \\
\text { 2013) }\end{array}$ & $\begin{array}{l}\text { Creation of ideas } \\
\text { Dissemination } \\
\text { Providing value }\end{array}$ & Organisational & $\begin{array}{l}\text { Creation of } \\
\text { ideas }\end{array}$ & Dissemination & Providing value \\
\hline $\begin{array}{l}\text { Positioning an organisation as a leader } \\
\text { through producing excellent content } \\
\text { (Bailyn, 2019) }\end{array}$ & $\begin{array}{l}\text { Excellent content } \\
\text { Brand awareness } \\
\text { positioning }\end{array}$ & Organisational & & & $\begin{array}{l}\text { Brand } \\
\text { awareness } \\
\text { positioning } \\
\text { Excellent } \\
\text { content }\end{array}$ \\
\hline $\begin{array}{l}\text { Entry point into a relationship that gives } \\
\text { people greater confidence in the } \\
\text { organisation (Rasmus, 2012) }\end{array}$ & $\begin{array}{l}\text { Relationship } \\
\text { Confidence }\end{array}$ & Organisational & & & $\begin{array}{l}\text { Confidence } \\
\text { Relationship }\end{array}$ \\
\hline $\begin{array}{l}\text { Client-centric and research-based } \\
\text { campaign or content with an original } \\
\text { approach or theme (Gulland Padfield, } \\
\text { 2019) }\end{array}$ & $\begin{array}{l}\text { Client-centred } \\
\text { Research-led } \\
\text { Originality }\end{array}$ & Organisational & $\begin{array}{l}\text { Research-led } \\
\text { Client-centred }\end{array}$ & & Originality \\
\hline $\begin{array}{l}\text { A strategy for growth. Organisations } \\
\text { sharing with clients what they are } \\
\text { known for (Llopis, 2014) }\end{array}$ & $\begin{array}{l}\text { Relationship } \\
\text { Sharing knowledge } \\
\text { Reputation-building } \\
\text { Growth }\end{array}$ & Organisational & & $\begin{array}{l}\text { Sharing } \\
\text { knowledge }\end{array}$ & $\begin{array}{l}\text { Growth } \\
\text { Relationship } \\
\text { Reputation- } \\
\text { building }\end{array}$ \\
\hline $\begin{array}{l}\text { Strategic approach to communication; } \\
\text { helping organisations to position and } \\
\text { differentiate; and enhance relationships } \\
\text { with key stakeholders (Pearce, 2013) }\end{array}$ & $\begin{array}{l}\text { Strategic } \\
\text { communication } \\
\text { Differentiation } \\
\text { Stakeholder } \\
\text { relationships }\end{array}$ & Organisational & & $\begin{array}{l}\text { Strategic } \\
\text { communication }\end{array}$ & $\begin{array}{l}\text { Differentiation } \\
\text { Stakeholder } \\
\text { relationships }\end{array}$ \\
\hline $\begin{array}{l}\text { Increasing visibility of specialised } \\
\text { expertise, building brand strength or } \\
\text { generating new business. Insightful } \\
\text { analysis targeted at key audiences } \\
\text { (Frederiksen and Tyreman, 2018) }\end{array}$ & $\begin{array}{l}\text { Insightful analysis } \\
\text { Visibility } \\
\text { Expertise } \\
\text { Brand building } \\
\text { Key audiences }\end{array}$ & Organisational & $\begin{array}{l}\text { Insightful } \\
\text { analysis } \\
\text { Expertise }\end{array}$ & Key audiences & $\begin{array}{l}\text { Visibility } \\
\text { Brand building }\end{array}$ \\
\hline $\begin{array}{l}\text { Recognised as an authority in selected } \\
\text { areas of specialisation (Prince and } \\
\text { Rogers, 2009) }\end{array}$ & $\begin{array}{l}\text { Authority } \\
\text { Specialisation }\end{array}$ & Organisational & & & $\begin{array}{l}\text { Authority } \\
\text { Specialisation }\end{array}$ \\
\hline $\begin{array}{l}\text { Outward expression of market } \\
\text { leadership (McKeon, 2009) }\end{array}$ & Market leadership & Organisational & & & $\begin{array}{l}\text { Market } \\
\text { leadership }\end{array}$ \\
\hline $\begin{array}{l}\text { Expert content that identifies new } \\
\text { trends and is supported by research. } \\
\text { It challenges the thinking of the target }\end{array}$ & $\begin{array}{l}\text { Expert } \\
\text { Research based }\end{array}$ & Organisational & $\begin{array}{l}\text { Research- } \\
\text { based } \\
\text { Expertise }\end{array}$ & & $\begin{array}{l}\text { Marketing } \\
\text { outcomes } \\
\text { Challenging }\end{array}$ \\
\hline
\end{tabular}

(continued) 


\section{Table 2}

\begin{tabular}{|c|c|c|c|c|c|}
\hline Abridged definition & Key themes & Scale of analysis & Input & Process & Outcome \\
\hline audience and drives marketing & Challenging & & & & \\
\hline outcomes (Crestodina, 2020) & Marketing outcomes & & & & \\
\hline $\begin{array}{l}\text { Ideas that educate customers about } \\
\text { prospects and educate them to solve }\end{array}$ & $\begin{array}{l}\text { Introducing new } \\
\text { prospects }\end{array}$ & Industry & & Education & $\begin{array}{l}\text { Introducing new } \\
\text { prospects }\end{array}$ \\
\hline those without selling & Stakeholders & & & & Stakeholders \\
\hline (Leavitt et al., 2016) & Education & & & & \\
\hline $\begin{array}{l}\text { Championing new ideas rather than } \\
\text { managing people or helping a group } \\
\text { achieve a goal (McCrimmon, 2005) }\end{array}$ & $\begin{array}{l}\text { New ideas } \\
\text { Goal achievement }\end{array}$ & Industry & & & $\begin{array}{l}\text { Goal } \\
\text { achievement } \\
\text { New ideas }\end{array}$ \\
\hline $\begin{array}{l}\text { Building a relationship with prospects } \\
\text { based on knowledge (Koch, 2009) }\end{array}$ & $\begin{array}{l}\text { Relationship } \\
\text { Knowledge }\end{array}$ & Industry & Knowledge & & Relationship \\
\hline $\begin{array}{l}\text { Content that answers the biggest } \\
\text { questions on the minds of the target } \\
\text { audience (Brenner, 2019) }\end{array}$ & $\begin{array}{l}\text { Big questions } \\
\text { Answers }\end{array}$ & Industry & Big questions & & Answers \\
\hline $\begin{array}{l}\text { Eminence achieved by producing and } \\
\text { delivering superior expertise that } \\
\text { solves significant problems (Buday, } \\
\text { 2011) }\end{array}$ & $\begin{array}{l}\text { Eminence } \\
\text { Expertise } \\
\text { Problem solving }\end{array}$ & Industry & Expertise & & $\begin{array}{l}\text { Eminence } \\
\text { Problem-solving }\end{array}$ \\
\hline $\begin{array}{l}\text { Advance marketplace of ideas by } \\
\text { positing actionable, commercially } \\
\text { relevant, research-backed viewpoints } \\
\text { (Alexander and Badings, 2012) }\end{array}$ & $\begin{array}{l}\text { Advance ideas } \\
\text { Research-led } \\
\text { Actionable } \\
\text { Commercial }\end{array}$ & Industry & Research-led & & $\begin{array}{l}\text { Commercial } \\
\text { actionable } \\
\text { Advance ideas }\end{array}$ \\
\hline
\end{tabular}

require tailoring the message through different mediums. Outcomes of thought leadership include results, reputation building, brand awareness, introducing new prospects, differentiation, visibility, brand building and influence. Finally, when removing considerations of inputs, processes and outcomes, the core elements of thought leadership from the literature involves actionable, providing value, solutions, eminence, trusted source and authority. Perceived value such as content that answers the biggest questions on the minds of the target audience is a key driver (Brenner, 2019). From this, we develop a revised clearer and cleaner definition that excludes the various characteristics (inputs, processes and outcomes) and focuses on core elements of thought leadership (see Figure 1):

Knowledge from a trusted, eminent and authoritative source that is actionable and provides valuable solutions for stakeholders.

\section{Figure 1 Enhancing a definition of thought leadership}

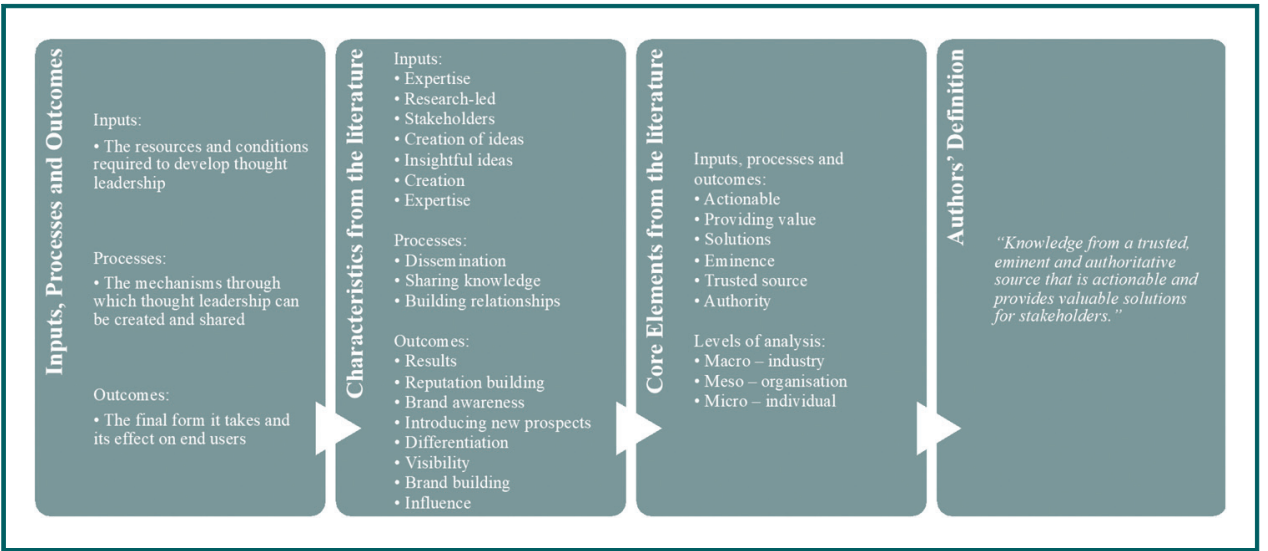




\section{Tensions and paradoxes in developing thought leadership}

We now explain the tensions and paradoxes in developing thought leadership at three different levels of analysis (see Table 3), focusing first on tensions at the level of the individual (micro level), then on tensions at the level of the organisation (meso level) and, finally, tensions at the level of the industry or sector (macro level).

\section{Individual-/micro-level tensions}

Thought leadership should intrigue, challenge and even inspire people already familiar with an organisation by generating new ideas and pushing boundaries, what Timo Elliott calls "Return on Interesting" or "Return on Ideas". Exploration of new knowledge involves "search, variation, risk taking, experimentation, play, flexibility, discovery, innovation" (March, 1991, p. 71). This generates new and unsettled knowledge with potentially high but uncertain returns that can be potentially relevant to several parts of an organisation, though which parts and in what ways is initially unknown. However, in an article by Andrew Hill (2017) in the Financial Times, he describes genuine thought leadership as "being swept away by a surfeit of self-serving surveys".

In interpreting these micro-level tensions, we draw on the notion of exploration versus exploitation of knowledge (Sudhir, 2016) and the paradoxes within innovation (Andriopoulos and Lewis, 2009). We suggest that exploitation, which generates incremental knowledge with moderate but certain and immediate returns and captures "refinement, choice, production, efficiency, selection, implementation, execution" (March, 1991, p. 71), is the dominant logic for thought leadership within KBOs. Our respondents' observations are echoed in a survey of legal marketers where $94 \%$ complain that partners drive them to produce similar content to competitors, and four in five complain that their firm is a hostile environment for new ideas. Even when generated, $83 \%$ of accountancy marketers say they struggle to stop ideas being diluted and three-quarters of chief marketing officers (CMOs) complain that their firm is too concerned about being seen to be negative or critical to say anything meaningful (Manbitesdog, 2014). How the two paradoxes of exploration and exploitation are balanced and managed within organisations (Knight and Harvey, 2015) regarding their thought leadership is problematic and has led to some individuals becoming trapped in a cycle of thought followership, copying competitors and releasing content that is already tried, tested and tired. This raises our first tension:

Individual tension 1. How can individuals balance the risk of thought leadership with the safety of thought followership so they do not damage their reputation among salient stakeholders?

One effective way to begin generating ideas for thought leadership is to identify all the questions that stakeholders are asking. To do this, some KBOs use online discussion forums; for example, the American Express Open Forum, the Mayo Clinic's site that answers patient questions, or H\&R Block and their selfless approach to answering tax-related questions. In part, an individual's level of authority is determined by how well he or she answers those most important questions that are posed by such audiences. This "give to get" approach ensures that self-promotion is not placed ahead of the relevance of thought leadership content to the audience. An alternative is to use existing customer and client challenges or projects which are gathered as part of the paid work for client organisations. As one respondent put it, the "new thought leadership" is about the democratisation of ideas. "Thought is more powerful from within - invite your stakeholders to debate and cocreate". The solutions created for these challenges then become a resource for developing thought leadership content. However, because clients act as co-innovators and new knowledge creators because of their ability to bring industry-specific understanding into the new knowledge production process (Bettencourt et al., 2002), this means individuals do not work alone to produce and then deliver solutions for clients (Broschak, 2015; Gallouj and Weinstein, 1997). Involving clients and client information in the development of thought 
Table 3 Levels of analysis and thought leadership tensions

\begin{tabular}{|c|c|}
\hline Level of analysis & Tensions with thought leadership \\
\hline Individual (micro-level) & $\begin{array}{l}\text { Individual tension } 1 \text {. How can individuals balance the risk of thought } \\
\text { leadership with the safety of thought followership so they do not } \\
\text { damage their reputation among salient stakeholders? } \\
\text { Individual tension } 2 \text {. How do individuals balance using the thought } \\
\text { leadership derived from client engagement, with the restrictions of } \\
\text { client confidentiality and intellectual property? } \\
\text { Individual tension 3. If thought leadership is supposed to be rare, } \\
\text { how can it become common for individuals to consistently produce? }\end{array}$ \\
\hline Organisational (meso-level) & $\begin{array}{l}\text { Organisational tension } 1 \text {. How can organisations effectively navigate } \\
\text { the tension between promoting "me" and "we"? } \\
\text { Organisational tension } 2 \text {. How should organisations decide which } \\
\text { and how much thought leadership to commission and co-brand (buy- } \\
\text { in) versus incentivise employees to develop (buy-out)? } \\
\text { Organisational tension } 3 \text {. How do organisations weigh up which } \\
\text { outcomes are worth the time and cost of measuring, and how can } \\
\text { they be attributed to thought leadership activities to establish a return } \\
\text { on investment? }\end{array}$ \\
\hline Industry (macro-level) & $\begin{array}{l}\text { Industry tension 1. How do knowledge-based industries navigate } \\
\text { longer term knowledge advancement for wider stakeholder benefit } \\
\text { compared to the narrower and short-term interests of satisfying the } \\
\text { immediate needs of customers and clients? } \\
\text { Industry tension 2. How can knowledge-intensive industries balance } \\
\text { sharing thought leadership with protecting proprietary knowledge? } \\
\text { Industry tension 3. Because tacit knowledge requires different } \\
\text { dissemination mechanisms, how can knowledge-intensive industries } \\
\text { effectively communicate thought leadership stemming from tacit } \\
\text { knowledge? }\end{array}$ \\
\hline
\end{tabular}

leadership can be problematic because some thought leadership knowledge developed from interaction with clients cannot be divulged for confidentially reasons, potentially restricting thought leadership possibilities. This raises a second individual tension:

Individual tension 2. How do individuals balance using the thought leadership derived from client engagement, with the restrictions of client confidentiality and intellectual property?

The original meaning of thought leadership recognised that:

in every community there are outstanding thought leaders. These progressive men and women set the pace for the entire field and they influence the thoughts and buying habits of their communities (Stewart, 1947, p. 29).

However, not everyone can be a thought leader because if everyone is challenging the status quo, there is no status quo to challenge. Yet, a survey of CMOs found that $82 \%$ of clients expected that firms will be thought leaders and produce insightful content (Manbitesdog, 2014). Respondents noted that this has created a demand among partners to constantly produce thought leadership content to convince different stakeholders that they can support their expertise claims. However, while partners are creating more thought leadership content, it is often not perceived by stakeholders (e.g. clients) as high quality or relevant to the KBO's claims around knowledge expertise (Harvey et al., 2017). A partner from a creative services agency said: "Thought leadership has become commoditised. If you have to say you are a thought leader you probably aren't". Our respondents observed that this was a difficult task, as reflected in $81 \%$ of marketing leaders confessing that their firm struggles to generate any genuinely new insights or points of view and more than a third (39\%) of CMOs acknowledge that their firm prioritises quantity over quality (Manbitesdog, 2014). Indeed, many CMOs admit that $62 \%$ of their own so-called thought 
leadership is in fact thought followership or the commercialisation of specialisation. Managing the challenge of having few or many thought leaders leads to our third individual tension:

Individual tension 3. If thought leadership is supposed to be rare, how can it become common for individuals to consistently produce?

\section{Organisational-/meso-level tensions}

One of the consequences of many individuals in an organisation attempting to produce their own thought leadership is that it is difficult to manage the overall organisational brand. Respondents noted that this issue revolves around how much of the thought leadership is at the individual level of "me" compared to at the organisational level of "we"? Pearce (2004) argues that it is increasingly difficult for one individual to hold all the knowledge required to do knowledge work, which is becoming increasingly team-based, particularly when the work relies on interdependence, creativity and complexity. Team-based knowledge work is another component of "we" as some, although not all, of the emphasis shifts from vertical leadership to shared leadership (Cox et al., 2003).

This raises several questions, the first of which is who is the owner of the thought leadership or to whom are the image and reputational benefits ascribed? How thought leadership affects and is affected by an organisation's objectives for image management (what it wants others to think about the organisation) may be different from its identity (how the organisation understands itself) and its reputation (how stakeholders actually perceive the organisation) (Brown et al., 2006), and therefore needs careful consideration. Second, because organisations usually need clarity around their reputation on the question of what they want to be known for, or what Lange et al. (2011) describe as "being known for something", how can they manage having many people developing new diverse thought leadership perceptions while maintaining a consistent reputation in the marketplace? If they do not clarify their distinctive qualities, they can end up promoting many things, resulting in their reputation becoming blurred and unclear from the communication "confetti". Indeed, almost half (46\%) of management consultancy CMOs admit that their approach to content has no clear strategy behind it and $58 \%$ of CMOs admit that strategy gets set aside by the need to produce high volumes of content (Manbitesdog, 2014). A third problem relates to stimulating and promoting individual thought leaders ("me") which involves rewarding independent thinking and developing voice and agency within any organisation, which can threaten existing joint power and leadership structures ("we"). Nguyen et al.'s (2019) meta-analysis finds that knowledgesharing behaviour is an outcome of both intrinsic and extrinsic motivators, meaning that individuals need to find that activity rewarding and be incentivised to participate, with the former having a stronger influence than the latter. This is particularly problematic within partnerships as this invariably means some individuals rise in prominence. This leads us to ask our first organisational tension:

Organisational tension 1. How can organisations effectively navigate the tension between promoting "me" and "we"?

There is an intense pressure to create thought leadership which satisfies our definition and that generates the right change in thinking to warrant the attention of the media and clients. To achieve this, two generic approaches can be adopted, namely, buy-in from an external provider or buy-out a partner's time to self-produce. Such practices reflect aspects of open innovation which is another important means of managing knowledge within organisations (Wu and $\mathrm{Hu}$ (2018: 1737). Outside-in approaches rely on the exploration of external sources, whereas insideout approaches entail opening up the innovation process for external sources and exploitation, and coupled approaches involve some combination of outside-in and inside-out approaches (Lichtenthaler and Ernst, 2009; Bellantuono et al., 2013). With the self-produce, inside-out model, 
associates and partners of many KBOs are expected to produce the thought leadership largely by themselves and are incentivised to do this. Certain organisations, such as McKinsey \& Company, where thought leadership is a key performance indicator for associates and principles, place particular value on this individual activity. With the buy-in approach, firms either do not believe their associates and partners can produce high-quality thought leadership or they do not think that the opportunity cost of doing so is worth it. Respondents noted that this can be particularly attractive for PSFs who are wedded to the billable hours model of operation. Here, KBOs often commission content providers to come up with original content and research, which is then branded in-house to help position them as thought leaders. Ashok et al. (2016) find that organisations who invest in knowledge management for radical change are those who have higher levels of innovativeness and have a greater appetite to search for new knowledge. However, the extraction of value from new and unknown sources requires a greater level of resources (Ashok et al., 2016) as well as a higher appetite for risk. As yet, the approaches chosen based on cost-benefit analyses are not clear, which leads to our second organisational tension:

Organisational tension 2. How should organisations decide which and how much thought leadership to commission and co-brand (buy-in) versus incentivise employees to develop (buyout)?

Despite increased investment in thought leadership, there is major confusion around how it is measured (Wittlake, 2015), and therefore what the impact of thought leadership is for organisations. Some of the most popular metrics noted by respondents include the number of content downloads, media hits, social media engagement, search engine ranking, client meetings, qualitative feedback, Web traffic, inbound Web links and quality and quantity of leads, client retention and sales revenue. As one respondent put it, "you can drown in "measures", if you don't know what you are looking for". There are several trade-offs and tensions here. First is the sheer volume and cost of things which can be measured, including the time and cost of analysing them. Second is the question of attribution of any effect to thought leadership. Attributing an uplift in the metrics above, especially financial returns, to specific thought leadership of individuals is difficult to determine. Our third organisational tension is therefore:

Organisational tension 3. How do organisations weigh up which outcomes are worth the time and cost of measuring, and how can they be attributed to thought leadership activities to establish a return on investment?

\section{Industry-/macro-level tensions}

Related to issues of individuals using client data and confidentiality is a wider macro issue of knowledge creation. The general concern is that broad scientific progress and visionary thought leadership will be stymied by client restrictions on data collection, interpretation and dissemination (Cohen et al., 1998). Evidence from when scientists work with customer organisations suggests that "researchers and users belong to separate communities with very different values and ideologies" (Beyer and Trice, 1982, p. 608). Respondents noted one of many such value conflicts is the social benefit versus profit trade-off when a piece of thought leadership which is beneficial to the industry, profession or society, means additional costs for some clients, for example sustainability or climate change practices. Worries exist that collaborating with practitioners may mean that only narrow, short-term or commercially profitable projects will be pursued (Murphy and Saal, 1990) or that managerial interests will be pursued at the expense of considerations for a wider group of stakeholders such as employees or members of the community (Fagenson-Eland, 1999). There are, therefore, concerns that knowledge and thought leadership creators can be subtly (Beyer and Trice, 1982) or not so subtly (e.g. Press and Washburn, 2000) co-opted by vested interests and incentives that restrict the level of thought leadership which can be 
developed by an industry. Given that customers and clients are highly price-sensitive and commercially focused, this raises the question of how much of a restriction this places on thought leadership which might need to have a wider agenda to be meaningful. As Wright (2019) notes, consultants' proposed responses to political instability, resource scarcity and ecological crises involve at most incremental changes to a dominantly neo-liberal vision of the future. This leads us to identify our first macro-level tension:

Industry tension 1. How do knowledge-based industries navigate longer term knowledge advancement for wider stakeholder benefit compared to the narrower and short-term interests of satisfying the immediate needs of customers and clients?

Thought leadership requires organisations to share with the world their expertise and knowledge by being transparent about their best practices and sharing them with potential clients. When in the public domain, this can be shared further. This is in line with many industries that are adopting more open innovation approaches (Chesbrough and Crowther, 2006) to capture external knowledge to enable them to innovate internally so that they can expand their market reach (West et al., 2014). Some find a positive effect of intellectual property rights on open innovation processes (Bican et al., 2017), and identify the benefits of long-term relationships, which thought leadership can help to establish, maintain and enhance (Wu and $\mathrm{Hu}, 2018$ ).

Surprisingly, the above literature does not take account of internal knowledge that is shared externally for the purposes of substantiating or corroborating organisational claims to customers and clients, or for increasing its reputation among different stakeholders. Respondents noted that for knowledge-based industries, this is problematic because perceptions around cutting-edge thinking, which includes thought leadership, have previously justified charging premium rates. As one respondent suggested: "PSFs are mistaken in thinking that producing and selling intellectual property is the way to become a thought leader". Worse still, the sharing of proprietary ideas, knowledge and know-how, essentially for free, not only lays bare to some degree the "black box" of organisational thinking, but also potentially reduces competitive advantage because competitors can more easily copy and steal intellectual property (Bican et al., 2017). Some have observed that when unpacked, the work of KBOs such as PSFs is far less knowledge-intensive than we might expect (Alvesson, 1993; Blackler, 1995). It also allows competitors to see what they know or do not know, as well as professional and regulatory bodies and potential clients.

At a firm and industry level, divulging much or any of the knowledge which previously would have been proprietary information about their knowledge and their clients for raising revenue appears to create a trade-off between demonstrating your knowledge and giving away your knowledge. This tension between promoting knowledge transfer inside the firm and preventing knowledge imitation from outside the firm has been previously recognised more broadly (Krylova et al., 2016). This highlights the paradoxical experiences for organisations of protecting and sharing information (Calic et al., 2019) and leads us to our second industry tension:

Industry tension 2. How can knowledge-intensive industries balance sharing thought leadership with protecting proprietary knowledge?

Embedded within the second industry tension, there is a further tension related to how to capture and convey tacit knowledge which is part of know-how. Here, a distinction between "know-what" and "know-how", which corresponds broadly with the differences between explicit and tacit knowledge (Polanyi, 1966), is relevant as tacit knowledge is central to the production process in KBOs (Faulconbridge, 2006; Marchant and Robinson, 1999). Externalisation is the process by which tacit knowledge is made explicit and where intuitions or images are converted into tangible statements, metaphors, analogies, hypotheses or 
models (Nonaka and Takeuchi, 1995, p. 64). It tries to codify tacit knowledge into transmittable formal, systematic language expressed in symbols, words and/or numbers, but this is difficult and a large part of tacit knowledge is naturally lost in the translation and aggregation process (Lam, 2000, p 495). However, Polanyi's felicitous phrase "we can know more than we can tell" (1966, p. 4), which is reflected in Lew Platt, Chairman of Hewlett-Packard's comment "If only HP knew what HP knows, we could be three times more productive!" (Davenport and Prusak, 1998, p. xii), acknowledges that some tacit knowledge is "imperfectly accessible to conscious thought" (Nelson and Winter, 1982, p. 79). Indeed,

Professionals perceive that their true value to their clients (and their source of power within their PSF) derives from their unique combination of experiences and intuition. They recognize that this knowledge is not susceptible to codification (Empson, 2001, p. 814).

Thus, it is not possible for some aspects of tacit knowledge to be codified as it "can only be produced in practice" (Maskell and Malmberg, 1999, p. 172) "because it defies easy explanation, it is best learned experientially" (Gertler, 2003, p. 5). Because the production of tacit knowledge occurs simultaneously with the act of transmission, primarily through the mechanism of user-producer interaction (Lundvall, 1988; Gertler, 1995), it is difficult to disseminate or share more widely and therefore be part of thought leadership. This raises the tension of how existing thought leadership capture and communication mechanisms such as newsletters, books, e-mails and social media posts are being used to convey tacit knowledge, and leads to our third industry tension:

Industry tension 3. Because tacit knowledge requires different dissemination mechanisms, how can knowledge-intensive industries effectively communicate thought leadership stemming from tacit knowledge?

\section{Discussion and research agenda}

\section{Managerial implications and areas for further research}

While we have introduced, defined and explored various tensions related to thought leadership, these provide several managerial implications as well as opportunities for future research which include how to resolve the tensions identified and the micro, meso and macro levels of producing thought leadership. In this section, we provide some insight into ways to manage the tensions identified as well as research directions in these areas to stimulate thinking and action on thought leadership by practitioners and academics.

Some argue that organisations are progressively more dependent on managing paradox (Ivory and Brooks, 2018). As a result, how these are managed becomes a potential area for competitive advantage. Here a paradox or tension lens helps to contribute to a process of action described as "working through" paradox (Luscher and Lewis, 2008). Rather than the contradiction being "traded-off", it might remain central to the approach and therefore central to the response (Smith and Lewis, 2011) and needed to be lived with, which requires "both/and" alternatives that foster novel and creative solutions (Lewis et al., 2014). We use these alternatives to illustrate how KBOs might approach the tensions we have identified and call for further research into these approaches.

One general approach to managing tensions is to identify both/and solutions that leverage synergies and distinctions of the opposing elements. For example, Individual tension 3 (see Table 3) is a paradox and the both/and solution might be to look at different levels of analysis we have proposed. This would involve viewing thought leadership that changes industries as being rare and consistent with normative understandings of true thought leadership, whereas thought leadership which changes an individual's behaviour is more common, but might not be considered true thought leadership. For Industry tension 1, the pragmatic approach of the industry needing to live with the paradox between developing thought leadership for short-term interests of immediate customer and client needs versus 
navigating longer term knowledge advancement for wider stakeholder benefit, would perhaps be most helpful. For Industry tension 3, a both/and solution to the paradox of tacit knowledge is only demonstrable when working on a client problem is a possibility. For example, some clients might allow for non-competing firms to view this form of working (perhaps at a price), or some clients could be given a taster session at a discounted price of the tacit knowledge applied by consultants of KBOs.

Another strategy for tackling tensions is to use trade-offs which exist between competing choices where no clear preference exists when the advantages and disadvantages of each are weighed up. Here the resolution is to maximise the advantages and limit the disadvantages with the understanding that opting for one choice impacts the benefits of the other. For example, for Organisational tension 2, the pros of buying-in thought leadership externally versus developing it in-house need to be considered. Further research is required into which model, buy-in or buy-out thought leadership, is more effective for different types of initiatives. In particular, the self-produced model carries greater authenticity but has implications which are greater than incentivisation. This requires the recruitment, selection and development of a different type of associate or partner, and therefore research into what types of organisational conditions are required to make both types of process work best is needed. For Organisational tension 3, KBOs need to trade off the time and cost of measuring thought leadership outcomes, with the benefits of knowing what the financial or reputational return has been. Research is needed into what reach, engagement and conversion metrics pass the cost-benefit test. Reach could be measured through Web traffic, search engine ranking, content views and downloads and media coverage. Engagement could be measured by time spent on thought leadership content, requests for additional information, direct and indirect qualitative feedback, number of events and participants and new institutional relationships. Conversion should have some measure of meaningful relationships with stakeholders, including e-mail sign-ups, number of client meetings, number of leads and mandates and revenue. In addition, outcomes from our table of definitions suggest that any measures of thought leadership effectiveness and return on investment need to consider outcomes such as growth, commercial results, reputation and relationship building, confidence, brand awareness, visibility, new prospects, differentiation, positioning and influence, eminence, market leadership, authority and problem-solving.

Compromise is the final tension resolution strategy and requires further attention. This includes the contradictory elements being resolved through an integration of different options and finding common ground. A candidate for adopting this strategy includes Organisational tension 1 which might necessitate a compromise to allow "me" messages which fit with the "we" message image of the firm. For Individual tension 2, compromise is needed between the amount of confidential client data used versus data that is released to create thought leadership. Similarly, for Industry tension 2, a blended option balancing some sharing of thought leadership which protects proprietary knowledge for the industry might be achieved. One partial compromise solution to Industry tension 2 is to consider what type of knowledge can be recognised, captured and communicated as thought leadership. As tacit knowledge is personal, context-specific knowledge, which includes cognitive patterning (mental models and schemata), technical knowledge (concrete, skill-related knowhow) and subjective insights (hunches), is difficult to formalise and communicate as thought leadership. Thought leadership is largely viewed in print or visible form as codified knowledge and may reflect only a small fraction of the total knowledge organisations produce. This would be a fruitful avenue for further research. Indeed, more research is needed to understand the processes of capturing and conveying tacit knowledge as part of thought leadership and to explore appropriate ways of conveying them to audiences.

\section{Levels of practical thought leadership}

Applying a knowledge-based perspective on thought leadership helps to distinguish between thought leadership, which is knowledge content that is original, valuable and 
actionable for stakeholders, and thought leaders, who are the actors (people, teams and organisations) that lead, manage and create the ideas and content at the organisational or industry level. This highlights how thought leadership is not only relevant at the industry as well as at the organisational and individual levels of analysis, but it can also change depending on these different levels, leading to other tensions, paradoxes and conceptual delineations. First, there are examples where this framework has been used effectively to shed light on communication issues and organisational theory (Kuhn, 2012; van Wijk et al., 2019). Second and specifically in our context, because PSFs are frequently structured as partnerships, the relevance of the individual nature of thought leadership versus the more common analysis level of the organisation is important. Like other work on organisational paradoxes (Hahn et al., 2015), we analyse thought leadership tensions and paradoxes at three different levels: industry, organisational and individual, which warrants a multiple level of analysis. Third, conceptually, some of the tensions identified clearly belong to one level of analysis only and this presents a coherent way to categorise them. For example, in Individual tension 2, the issue of how do individuals balance using the thought leadership derived from client engagement, with the restrictions of client confidentiality and intellectual property, is clearly an individual trade-off and much less applicable to other levels of analysis because in PSFs, governance is focused on the individual through professional bodies, rather than the organisation. In addition, for Organisational tension 1, with how organisations can effectively navigate the tension between promoting "me" and "we", this tension is mainly a concern for organisations, and is less relevant for the industry or an individual. Fourth, from the data, we provide in Figure 2, there are clearly empirical examples of thought leadership at all three levels which have very disparate questions and marketing issues surrounding them. As a result, this framework provides a clear analysis tool to help separate out different issues.

The three-level framework is effective given the breadth of thought leadership and can be illustrated by several pertinent examples. At the macro or industry level (e.g. the PWC Global CEO survey, KPMG's cost boomerang report or EY's ITEMost Club), thought leadership is arguably a broader commitment than lead generation, with an effort to benefit an industry as a whole and not just one's own organisation (McKeon, 2009). Second, at the meso/organisational level, it can be about the culture of an organisation (e.g. Netflix CEO Reed Hastings published a 126-page slide deck outlining how he hires, fires and rewards employees). Here, thought leadership is about the creation and dissemination of ideas that tend to result in advantages for organisations (Young, 2013). Third, at the micro/individual level, thought leadership can help people in their work or thinking (e.g. Grant Thornton's work on clear tax planning or KWM's Dial into China). Here, individuals become informed opinion leaders and the "go-to" people in their field of expertise. They are trusted sources who move and inspire people with innovative ideas, turn ideas into reality and know and show how to replicate their success (Brosseau, 2013). These examples provide insights and the confidence to analyse thought leadership within KBOs through these three levels of analysis.

An additional implication and avenue for further research comes from looking at the differences in how thought leadership is executed at the three levels of analysis. Different levels of thought leadership can help to identify a set of executional characteristics when considering thought leadership. These include the degree of originality of the thought leadership, the reach or number of people it could impact, the nature of the audience, the quantity/quality trade-off in terms of how much versus how substantive the thought leadership is, the frequency of release, the communication medium most likely to be used and the marketing objective considered. Using these, we were able to make a prima facie case for how they might vary between the three levels of analysis which may be helpful for organising how thought leadership is managed (see Figure 2). Of particular interest is the characteristic of originality. Den Hertog (2000) suggests four dimensions of novelty or new knowledge for knowledge-intensive firms, namely, service concept, client interface, service 


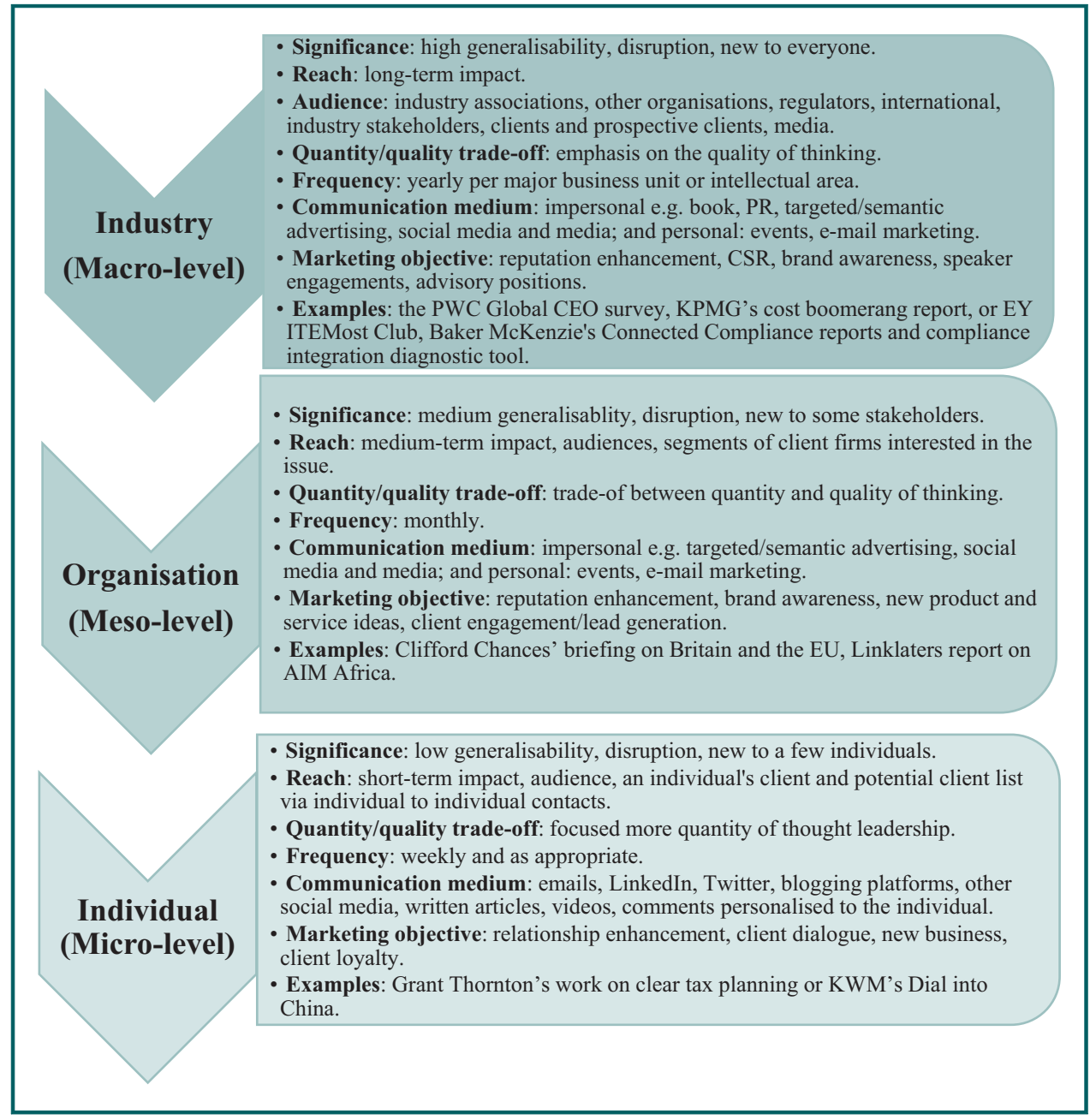

delivery system and technology, and many service innovations involve some combination of these four dimensions (Miles, 2008). However, further research is needed into what constitutes originality. From a practical viewpoint, the different levels of analysis help us to separate out how thought leadership might be executed at these different levels. Further practitioner work could help to validate existing and identify additional characteristics.

\section{Theoretical insights for further research in knowledge management}

Having explored some tensions and paradoxes in creating thought leadership, in this section, we identify multi-disciplinary areas of literature and theories that could be foundational for extending the thought leadership research agenda within the field of knowledge management. In doing so, we form several propositions that derive from them at the individual/micro level, the organisational/meso level and the industry/macro level. Our aim is to bring a richer perspective to knowledge management through emphasising how tensions are implicated in knowledge management through thought leadership.

In separating out the tensions at different levels, we must be careful not to imply that the tension exclusively pertains to only one level of analysis and does not involve other levels in any resolution. For example, for Individual tension 1 about how individuals balance the risk 
of thought leadership with the safety of thought followership so they do not damage their reputation among salient stakeholders, this could also be a strategic decision for the organisation as well as an individual issue. For Organisational tension 2 concerning how organisations decide which and how much thought leadership to commission and co-brand (buy-in) versus incentivise employees to develop (buy-out), this could also require the cooperation and input of individuals as they are involved in this decision. For Industry tension 2 which questions how knowledge-intensive firms balance sharing thought leadership with protecting proprietary knowledge, this issue is of concern to firms as well as sometimes individuals who have developed proprietary knowledge and use this to gain a competitive advantage.

Between our micro, meso and macro levels of analysis, general research questions arise regarding how thought leadership interacts at different levels of knowledge management, and whether a top-down, bottom-up or hybrid approach is more effective for legitimising thought leadership among multiple stakeholders in different contexts. While Bican et al. (2017) highlight various levels where open innovation may occur in knowledge management (firm, project and individual), it is not only the individual, team and organisational level that is important, but also what kinds of activities are occurring across sectors and industries. As an example, one issue which transcends all three levels is who decides what is thought leadership? There are a range of salient stakeholders who influence this decision, both within and outside of the firm, especially macro-level intermediaries and third parties such as endorsing bodies, professional bodies, respected media outlets and universities. Referring back to our definition of thought leadership as: "Knowledge from a trusted, eminent and authoritative source that is actionable and provides valuable solutions for stakeholders", influencers could be involved in deciding this a priori, or the decision could be made post hoc when information on how actionable it was and what value it created is known. An important corollary consideration is to understand what and how thought leadership is valuable for different groups for the sake of knowledge management. This would help to inform the different pathways through which thought leadership can be communicated and consumed.

\section{Leadership literature implications}

Because thought leadership includes the term leadership, this raises the possibility that theories of leadership can help to inform how thought leadership influences the thinking and behaviours of different stakeholders from a tension-based perspective (McCrimmon, 2005). Bertoldi et al. (2018), for example, highlight the importance of the knowledge-oriented leader who needs to keep pace with external changes so that new knowledge can be acquired from the external environment. Leadership as a concept may help to better understand the processes and outcomes of thought leadership because it is a process of social influence that shapes thinking, behaviours and relationships (Bolden et al., 2011, p. 39).

While theories of leadership have emphasised the importance of relationships, for example leader-member exchange theory (Graen and Uhl-Bien, 1995), relational leadership (Uhl-Bien, 2006; Cunliffe and Eriksen, 2011), shared leadership (Pearce, 2004) and interactions between leaders and followers (see also Kellerman, 2008, on followership), this body of work could also inform how thought leadership fosters knowledge exchange and relationship management which were identified as key themes in our analysis of definitions. An important extension of this literature is understanding how different types of thought leadership impact on the nature of relationships between leaders and followers and allow for tensions to be held in balance. Ashok et al. (2016) find that continuous communication channels and knowledge exchange enhance the value of co-creation between service providers and their clients. How leaders engage with thought leadership is a further means of forming 
and consolidating relationships with their stakeholders, particularly through empowering people to champion new ideas (McCrimmon, 2005).

Additionally, because effective leadership can provide organisations with the right climate to stimulate knowledge sharing and foster product and process innovation (Le and Lei, 2019), the same could apply to how thought leadership is deployed and impacts on the thinking and behaviours of different stakeholders. However, there are many theories of leadership, including transactional and transformational (Bass and Avolio, 1994; see also Le and Lei, 2019 in relation to knowledge sharing and innovation traits), trait approaches (Carlyle, 1966), authentic (Avolio and Gardner, 2005) and responsible leadership (Maak and Pless, 2006). Some argue thought leadership must be cultivated as a form of distributed leadership in any organisation (McCrimmon, 2005), but that it is very different from "shared leadership" or "leaderful" behaviour, both of which are based on the usual mixture of management and leadership ideas whereby the person in charge of a group, formally or otherwise, initiates new strategic directions and manages their implementation (McCrimmon, 2005). This helps to highlight how different levels of analysis might require different leadership theories to be adapted with respect to inside the organisation (micro and meso) where control and management is high, and with respect to outside the organisation (macro) where control and management is low.

Further research applying these leadership theoretical lenses to thought leadership would be fruitful for understanding how leaders can influence behaviour through the medium of thought leadership. Most theories show the importance of leaders engaging with a wide range of stakeholders over time, which necessitates creating and maintaining social capital, particularly through disseminating digital content through social media (Barry and Gironda, 2019) where authors are ascribed authority within their social networks (Maak, 2007). Thought leadership is another medium for leaders and organisations to show their value to their stakeholders, which influences behaviour even if is it not always sharply determined and pre-defined. Hence, we propose:

Theoretical proposition 1. The effectiveness of leaders is enhanced when they demonstrate thought leadership.

\section{Personal and organisational risk reduction}

Because of the complexity of KBOs such as PSFs and the intangible and co-produced nature of outputs, this creates uncertainty for clients (Alvesson, 1993; Glückler and Armbrüster, 2003). To reduce this risk, clients engage in many different behaviours from shared decision-making to pilot projects. Indeed, work using a risk framework in PSFs suggests risk-reducing concepts such as clarifying, simplifying and risk-sharing are helpful (Mitchell et al., 2003). These risk-reducing strategies can be deployed at an organisational level, for example, being the most well-known firm, as well as by individual practitioners, for example, demonstrating the prior experience of the professional. Using a risk framework, being recognised as a leading thinker whose thoughts have been externally validated, particularly by reputable stakeholders, can potentially act to reduce client risk around the successful outcome of projects. Clients associate thought leadership with greater experience and expertise as well as with innovative solutions and delivery of assumptionbreaking novel project outcomes (Heath et al., 2013). In addition, appointing recognised thought leaders can act as a political risk reducer, should the project not live up to expectations as clients can say that they appointed the best service provider in the field. This relates to von Nordenflycht's (2010) argument that clients rely on reputation and social proof as substitutes for measurable results when making procurement decisions. Therefore, one theoretical perspective is that thought leadership, either by individuals or at the organisational level, can act to reduce the risk for the client of achieving the results they desire (Mitchell, 1995; Mitchell, 2003) because it provides reassurance around expertise 
which can be difficult to judge in KBOs. This leads us to ask what role thought leadership plays in affecting risk perception and risk reduction activities and propose that:

Theoretical proposition 2. Organisations who produce high-quality thought leadership are perceived by clients as less risky service providers.

\section{Personal or organisational quality signalling}

One factor which exacerbates risk is that KBOs such as PSFs and their clients have a highly asymmetrical information relationship because many jobs are bespoke and therefore unique. In addition, client confidentiality often prevents other clients from seeing previous work, meaning the outcomes are uncertain as they depend on multiple parties and often involve the input of clients themselves through the co-production of knowledge (Brivot, 2011). Spence (1973) proposes that two parties could get around the problem of asymmetric information by having one party send a signal that would reveal some piece of relevant information to the other party. In other words, signals are a way for organisations to reduce information asymmetries and uncertainty for different groups (Bergh et al., 2010). At an individual level too, Blumer's (1969) signalling theory suggests the meaning of things determine how people act towards them and meaning arises out of the social interaction that one has with others and society (i.e. what an individual or firm does with the thought leadership), which modifies the meaning through an interpretative process.

In a context of decision uncertainty and information asymmetries, the quality of thought leadership is an important signal that can influence client perceptions of the likely quality of service they will receive from providers. However, what is unclear is what characteristics of thought leadership act as signals of quality. This is important because perceived quality is a known building block of reputation (Ridova et al., 2005; Lange et al., 2011) so if organisations can signal quality through thought leadership to different stakeholders, which may include intermediaries (Feller et al., 2009), then this is likely to have positive effects on their reputations. This would be a fruitful avenue for research and leads us to propose:

Theoretical proposition 3. The greater the quality signals of thought leadership, the higher its perceived value among clients.

\section{Managing social relationships}

Finally, thought leadership is disseminated through relationships between organisations as well as individuals and their stakeholders, and the knowledge and resources transferred through these networks (human and social capital). This poses potential links to social network theory which refers to the social contacts between different individuals or organisations, and social capital theory which refers to the resources which are embedded in and exchanged through these networks (Putnam, 2000; Lin et al., 2001). Here, the industry level is also important because sector, professional and regulatory events are important ways that new knowledge is shared and legitimised through social networks beyond the immediate networks of individuals and organisations. Network theorists refer to the importance of novel information being transferred through weak ties, which is the predominant type for thought leadership, because such ties, like acquaintances, tend to have access to different information than strong ties such as colleagues and friends (Granovetter, 1995; Lin, 2001). That said, thought leadership is a potentially important entry route to initiate relationships with new groups (weak ties) and a key medium for maintaining and enhancing relationships with groups who they already hold relationships (strong ties). For example, institutional theorists refer to professionals having the "social skills" to motivate others to cooperate in a change process (Fligstein, 2001). But how these social skills help to explain thought leadership effects and translate them into "social proofs" (von Nordenflycht, 2010) is unknown. Network theory could help in mapping how thought leadership material is 
spread through networks at a micro, meso or macro level and how such content gathers legitimacy in doing so as well as the role of thought leadership in effectively building, maintaining and enhancing social relationships within these networks. Hence, we expect that:

Theoretical proposition 4. Social network theories help to explain how thought leaders attract, retain and enhance relationships with different groups.

Theoretical proposition 5. Industries with better social networks result in greater impacts of thought leadership.

\section{Conclusions}

If handled well, thought leadership can be a major source of reputation advantage for individuals, teams and organisations through signalling knowledge distinctiveness compared to their peer set and competitors. However, given the tensions identified and the difficulties of measuring the effectiveness of thought leadership compared to other ways to measure reputation (Sarstedt et al., 2013; Ravasi et al., 2018; Pollock et al., 2019), it is timely to consider how we might better theorise how thought leadership is generated, projected, interpreted, measured and legitimised.

In answer to our first ambition to revisit what is thought leadership, we enhance current understandings by defining it as follows: "Knowledge from a trusted, eminent and authoritative source that is actionable and provides valuable solutions for stakeholders". From this perspective, much of what is produced as thought leadership does not pass the "valuable solutions" test. Hence, it is not surprising that some scholars and practitioners consider it as yet another management fad (Hall, 2019; Kellaway, 2007; Spicer, 2017). Moreover, by analysing definitions using an inputs, processes, outcomes and outputs framework, we demonstrate to other knowledge management scholars the value of this approach when faced with other areas of conceptual confusion.

Our second contribution reveals the hitherto hidden challenges for why so much thought leadership might not pass the valuable solutions test because of the tensions and paradoxes involved in creating, developing, sharing and promoting thought leadership. We identify nine tensions at a micro, meso and macro levels that individuals, teams and organisations may need to navigate when developing a thought leadership strategy (see Table 3).

For our third question, we focus on the implications of our tensions, and build on the work of Andriopoulos and Lewis (2009) to explore how these tensions can be managed through living with the paradox, trading-off options and finding compromising solutions. In addition to further exploration into these areas, we advocate for more research into the several theoretical propositions we propose for how and why thought leadership might work, including through leadership, reducing risk, signalling quality and managing social networks. In outlining our five theoretical propositions, we recognise that we cover some well-established fields of academic enquiry which may be considered a limitation because of its breadth, but this was a deliberate choice to avoid narrowing our theoretical frame of reference because we feel that thought leadership cuts across multiple disciplinary and theoretical boundaries. Further research is needed to test the usefulness of managing these tensions and our theoretical propositions.

Although we have uncovered much, there are general questions about our tensions that remain for further research, including, whether these tensions identified are all equally important, which tensions need to be addressed first and whether others can be identified. Further research might consider the role of firm size, the knowledge services provided, the degree of competitive secrecy of knowledge and the relative degree of competition because factors might change the relative importance of tensions and/or be sources of new 
tensions. We have sought to encourage scholars and practitioners to explore how thought leadership, which is a well-known but poorly understood phenomenon, can be more effectively theorised and applied in different contexts. We hope that our broad and inclusive approach will inspire both cross-disciplinary and academic-practitioner collaborations to the field of thought leadership.

\section{Limitations}

Finally, we note the limitations of our work, including sample, topic and theoretical limitations. Clearly, there may be slightly different tensions if the sample of firms was widened to include consultancies such as product design, engineering services, human resource, IT, marketing and sales. Therefore, we cannot generalise to these types of organisations. We interviewed a small number of elite participants who had a unique insight into thought leadership. However, while the limited number of exploratory interviews, supplemented by secondary data, has provided important insights, the sources and methods of data limits our theorisation to wider contexts. Clearly, more in-depth interviews at multiple levels within the organisation together with surveys and document analysis that reach wider groups could lead to more refined or new tensions. Finally, while we have sought to draw on some relevant theoretical perspectives as a way to stimulate researchers in this area, this is not an exhaustive review of relevant theories or frameworks. Hence, we hope that these limitations present opportunities for scholars to further enhance our understanding and application of thought leadership within knowledge-intensive firms.

\section{References}

Alexander, L. and Badings, C. (2012), \# Thought Leadership Tweet Book01: 140 Prompts for Designing and Executing an Effective Thought Leadership Campaign. Happy About, Cupertino, CA.

Alvesson, M. (1993), "Organizations as rhetoric: Knowledge-intensive firms and the struggle with ambiguity", Journal of Management Studies, Vol. 30 No. 6, pp. 997-1015.

Andriopoulos, C. and Lewis, M.W. (2009), "Exploitation-exploration tensions and organizational ambidexterity: managing paradoxes of innovation", Organization Science, Vol. 20 No. 4, pp. 696-717.

Ashok, M., Narula, R. and Martinez-Noya, A. (2016), "How do collaboration and investments in knowledge management affect process innovation in services?" Journal of Knowledge Management, Vol. 20 No. 5, pp. 1004-1024.

Avolio, B.J. and Gardner, W.L. (2005), "Authentic leadership development: getting to the root of positive forms of leadership”, Leadership Quarterly, Vol. 16 No. 3, pp. 315-338.

Bailyn, E. (2019), "Thought Leadership vs content marketing: what you need to Know", available at: https:// firstpagesage.com/seo-blog/thought-leadership/thought-leadership-vs-content-marketing-what-you-need-toknow-fc/

Barry, J.M. and Gironda, J.T. (2017), "Operationalizing thought leadership for online B2B marketing", Industrial Marketing Management, Vol. 81, pp. 138-159.

Bass, B.M. and Avolio, B.J. (1994), Improving Organizational Effectiveness Through Transformational Leadership, Sage Publications, Thousand Oaks, CA.

Baumeister, R.F. and Leary, M.R. (1997), "Writing narrative literature reviews", Review of General Psychology, Vol. 1 No. 3, pp. 311-320.

Bellantuono, N., Pontrandolfo, P. and Scozzi, B. (2013), "Different practices for open innovation: a context-based approach”, Journal of Knowledge Management, Vol. 17 No. 4, pp. 558-568.

Beyer, J.M. and Trice, H.M. (1982), "The utilization process: a conceptual framework and synthesis of empirical findings”, Administrative Science Quarterly, pp. 591-622. 
Bergh, D.D., Ketchen Jr, Boyd D.J.B.K. and Bergh, J. (2010), "New frontiers of the reputation performance relationship: insights from multiple theories", Journal of Management, Vol. 36 No. 3, pp. 620-632.

Bertoldi, B., Giachino, C., Rossotto, C. and Bitbol-Saba, N. (2018), "The role of a knowledge leader in a changing organizational environment. A conceptual framework drawn by an analysis of four large companies", Journal of Knowledge Management, Vol. 22 No. 3, pp. 587-602.

Bettencourt, L.A., Ostrom, A.L., Brown, S.W. and Roundtree, R.I. (2002), "Client co-production in knowledge-intensive business services", California Management Review, Vol. 44 No. 4, pp. 100-128.

Bican, P.M., Guderian, C.C. and Ringbeck, A. (2017), "Managing knowledge in open innovation processes: an intellectual property perspective", Journal of Knowledge Management, Vol. 21 No. 6, pp. 1384-1405.

Blackler, F. (1995), "Knowledge, knowledge work and organizations: an overview and interpretation", Organization Studies, Vol. 16 No. 6, pp. 1021-1046.

Blumer, H. (1969), Symbolic Interactionism; Perspective and Method, Prentice-Hall, Englewood Cliffs, NJ.

Boland, R.J., Singh, J., Salipante, P., Aram, J.D., Fay, S.Y. and Kanawattanachai, P. (2001), "Knowledge representations and knowledge transfer", Academy of Management Journal, Vol. 44 No. 2, pp. 393-417.

Bolden, R., Hawkins, B., Gosling, J. and Taylor, S. (2011), Exploring Leadership. Individual, Organizational \& Societal Perspectives. Oxford University Press, Oxford.

Braun, V. and Clarke, V. (2006), "Using thematic Analysis in Psychology," Qualitative Research in Psychology, Vol. 3 No. 2, pp. 77-101.

Brenner, M. (2019), "What is thought leadership? And when you should use it?", Marketing Insider Group, available at: https://marketinginsidergroup.com/content-marketing/what-is-thought-leadership-andwhen-you-should-use-it/ (accessed 26 August 2020).

Brivot, M. (2011), "Controls of knowledge production, sharing and use in bureaucratized professional service firms", Organization Studies, Vol. 32 No. 4, pp. 489-508.

Broschak, J.P. (2015), "Client relationships in professional service firms", in Empson, L., Muzio, D., Broschak, J.P. and Hinings, B. (Eds), The Oxford Handbook of Professional Service Firms, Oxford University Press, Oxford, pp. 304-326.

Brosseau, D. (2013), Ready to be a Thought Leader? How to Increase your Influence, Impact, and Success, Jossey-Bass, San Francisco, CA.

Brown, T.J., Dacin, P. A., Pratt, M.G. and Whetten, D.A. (2006), "Identity, intended image, construed image, and reputation: an interdisciplinary framework and suggested terminology", Journal of the Academy of Marketing Science, Vol. 34 No. 2, pp. 99-106.

Buday, B. (2011), "The hidden value of thought leadership", Buday Thought Leadership Partners, available at: https://budaytlp.com/2011/02/15/the-hidden-value-of-thought-leadership/

Calic, G., Hélie, S., Bontis, N. and Mosakowski, E. (2019), "Creativity from paradoxical experience: a theory of how individuals achieve creativity while adopting paradoxical frames", Journal of Knowledge Management, Vol. 23 No. 3, pp. 397-418.

Carlyle, T. (1966), On Heroes, Hero-Worship and the Heroic in History, John Wiley and Sons, New York.

Carollo, L. and Guerci, M. (2018), "'Activists in a suit': paradoxes and metaphors in sustainability managers' identity work", Journal of Business Ethics, Vol. 148 No. 2, pp. 249-268.

Carroll, J. and Swatman, P. (2000), "Structured-case: a methodological framework for building theory in information systems research”, European Journal of Information Systems, Vol. 9, pp. 235-242.

Chen, S. and Lin, N. (2016), "Global dispersion of offshore service providers: an information processing perspective", Journal of Knowledge Management, Vol. 20 No. 5, pp. 1065-1082.

Chesbrough, H.W. and Crowther, A.K. (2006), "Beyond high-tech: early adopters of open innovation in other industries", R\&D Management, Vol. 36 No. 3, pp. 229-236.

Chu, K.-W. (2016), "Leading knowledge management in a secondary school", Journal of Knowledge Management, Vol. 20 No. 5, pp. 1104-1147. 
Cohen, M.B. (1998), "Perceptions of power in client/worker relationships", Families in Society, Vol. 79 No. 4, pp. 433-442.

Coleman, L. and Casselman, R.M. (2016), "Optimizing decisions using knowledge risk strategy", Journal of Knowledge Management, Vol. 20 No. 5, pp. 936-958.

Cox, J.F. Pearce, C.L. and Perry, M.L. (2003), "Toward a model of shared leadership and distributed Influence in the innovation process: how shared leadership can enhance new product development team dynamics and effectiveness". in Pearce, C.L. and Conger, J.A. (Eds), Shared Leadership: Reframing the Hows and Whys of Leadership. SAGE Publications, Inc, Thousand Oaks, CA, pp. 48-76.

Crestodina, A. (2020), "What is thought leadership marketing? A new definition for marketers based on research", available at: www.orbitmedia.com/blog/what-is-thought-leadership-marketing/ (accessed 26 August 2020).

Cunha, M.P. and Clegg, S. (2018), "Persistence in paradox", in Farjon, M., Smith, W., Langley, A. and Tsoukas, H. (Eds), Perspective on Process Organization Studies Dualities, Dialectics and Paradoxes in Organaztional Life, Oxford University Press, Oxford, pp. 14-34.

Cunliffe, A.L. and Eriksen, M. (2011), "Relational leadership", Human Relations, Vol. 64 No. 11, pp. $1425-1449$.

Davenport, T.H. and Prusak L. (1998), Working Knowledge. How organizations manage what they know. Harvard Business Press, Cambridge, MA.

Edelman (2019), "2019 B2B thought leadership impact study", available at: www.edelman.com/ research/2019-b2b-thought-leadership-impact-study (accessed 26 August 2020).

Empson, L.A. (2001), "Fear of exploitation and fear of contamination: impediments to knowledge transfer in mergers between professional service firms", Human Relations, Vol. 54 No. 7, pp. 839-862.

Fagenson-Eland, E.A. (1999), "Thinking outside the box: a commentary on Lynn Luckow's chapter", Impact Analysis: How Research Can Enter Application and Make a Difference, pp. 115-121.

Faulconbridge, J.R. (2006), "Stretching tacit knowledge beyond a local fix? Global spaces of learning in advertising professional service firms", Journal of Economic Geography, Vol. 6 No. 4, pp. 517-540.

Feller, J., Finnegan, P., Hayes, J. and O'Reilly, P. (2009), "Institutionalising information asymmetry: governance structures for open innovation", Information Technology and People, Vol. 22 No. 4, pp. 297-316.

Fligstein, N. (2001), "Social skill and the theory of fields", Sociological Theory, Vol. 19 No. 2, pp. 105-125.

Flynn, L.R., Goldsmith, R.E. and Eastman, J.K. (1996), "Opinion leaders and opinion seekers: two new measurement scales", Journal of the Academy of Marketing Science, Vol. 24 No. 2, 137-147.

Forrester (2013), available at: http://blogs.forrester.com/laura_ramos/13-09-11-thought_leadership_ hot_topic_at_cs_forum_helsinki_2013 (accessed 26 August 2020).

Frederiksen, L. and Tyreman, J. (2018), "Creating and promoting an expertise-driven brand", Journal of Digital and Social Media Marketing, Vol. 6 No. 2, pp. 110-117.

Friese, S. (2014), Qualitative Data Analysis with ATLAS.ti, Sage Publications, London.

Gallouj, F. and Weinstein, O. (1997), "Innovation in services", Research Policy, Vol. 26 Nos 3/4, pp. 537-556.

Gardner, H.K. (2015), “When senior managers won't collaborate. Lessons from professional service firms", Harvard Business Review, Vol. 93 No. 3, pp. 74-82.

Gertler, M.S. (1995), "'Being there': proximity, organization, and culture in the development and adoption of advanced manufacturing technologies", Economic Geography, Vol. 71 No. 1, pp. 1-26.

Gertler, M.S. (2003), "Tacit knowledge and the economic geography of context, or the undefinable tacitness of being (there)", Journal of Economic Geography, Vol. 3 No. 1, pp. 75-99.

Glückler, J. and Armbrüster, T. (2003), "Bridging uncertainty in management consulting: the mechanisms of trust and networked reputation", Organization Studies, Vol. 24 No. 4, pp. 269-297.

Graen, G.B. and Uhl-Bien, M. (1995), "Relationship-based approach to leadership: development of leader-member exchange (LMX) theory of leadership over 25 years: applying a multi-level multi-domain perspective", Leadership Quarterly, Vol. 6 No. 2, pp. 219-247. 
Granovetter, M. (1995), Getting a Job: A Study of Contacts and Careers. Chicago University Press, Chicago.

Grant, S.B. (2016), "Classifying emerging knowledge sharing practices and some insights into antecedents to social networking: a case in insurance", Journal of Knowledge Management, Vol. 20 No. 5, pp. 898-917.

Gulland Padfield (2019), "The thought leadership trends of the world's leading law firms", Gulland Padfield publishes Review of Global Law Firm Insights and Publications, available at: www. gullandpadfield.com/articles/thought_leadership_assessment_2016

Hahn, T. and Knight, E. (2019), "The ontology of organizational paradox: a quantum approach", Academy of Management Review.

Hahn, T., Pinkse, J., Preuss, L. and Figge, F. (2015), "Tensions in corporate sustainability: towards an integrative framework", Journal of Business Ethics, Vol. 127 No. 2, pp. 297-319.

Hall, J. (2019), "Is thought leadership everything it's cracked up to be?", Forbes, available at: www. forbes.com/sites/johnhall/2019/11/03/is-thought-leadership-everything-its-cracked-up-to-be/ \#54e0c0d99341 (accessed 26 August 2020).

Harvey, W.S. (2011), "Strategies for conducting elite interviews", Qualitative Research, Vol. 11 No. 4, pp. 431-441.

Harvey, W.S., Morris, T. and Müller Santos, M. (2017), "Reputation and identity conflict in management consulting", Human Relations, Vol. 70 No. 1, pp. 92-118.

Heath, D., Singh, R., Ganesh, J. and Taube, L. (2013), "Building thought leadership through business-to-business social media engagement at Infosys", MIS Quarterly Executive, Vol. 12 No. 2, pp. 77-92.

Hertog, P.D. (2000), "Knowledge-intensive business services as co-producers of innovation", International Journal of Innovation Management, Vol. 4 No. 4, pp. 491-528.

Hill, A. (2017), "Stop thought leaders from turning useful ideas into pap", Financial Times, available at: www.ft.com/content/820ce98e-9327-11e7-a9e6-11d2f0ebb7f0 (accessed 26 August 2020).

House of Commons. (2018), "Digital, culture, media and sport committee. Disinformation and 'fake news': interim report: government response to the committee's fifth report of Session 2017-19", available at: https:// publications. parliament.uk/pa/cm201719/cmselect/cmcumeds/1630/1630.pdf (accessed 26 August 2020).

Howitt, D. and Cramer, D. (2010), Introduction to Research Methods in Psychology, 3rd ed., Pearson, Essex.

Huo, W., Cai, Z., Luo, J., Men, C. and Jia, R. (2016), "Antecedents and intervention mechanisms: a multilevel study of R\&D team's knowledge hiding behavior”, Journal of Knowledge Management, Vol. 20 No. 5, pp. 880-897.

Hussein, M.E., Hirst, S., Salyers, V. and Osuji, J. (2014), "Using grounded theory as a method of inquiry: advantages and disadvantages", The Qualitative Report, Vol. 19 No. 27, pp. 1-15.

Isabella, L. (1990), "Evolving interpretations as a change unfolds: how managers construe key organizational events", Academy of Management Journal, Vol. 33 No. 1, pp. 7-41.

Ivory, S.B. and Brooks, S.B. (2018), "Managing corporate sustainability with a paradoxical lens: lessons from strategic agility", Journal of Business Ethics, Vol. 148 No. 2, pp. 347-361.

Kellaway, L. (2007), "Leaders in need of a good idea", Financial Times, available at: www.ft.com/content/ 42b12720-9f65-11dc-8031-0000779fd2ac (accessed 26 August 2020).

Kellerman, B. (2008), Followership: How followers are creating change and changing leaders, Harvard Business School Press, Cambridge, MA.

Kerns, C.D. (2019), "Leading thought leadership: a practice-oriented framework", International Leadership Journal, Vol. 11 No. 1, pp. 3-41.

Khvatova, T., Block, M., Zhukov, D. and Lesko, S. (2016), "How to measure trust: the percolation model applied to intra-organisational knowledge sharing networks", Journal of Knowledge Management, Vol. 20 No. 5, pp. 918-935.

Koch, G. (2009), "Intercultural communication and competence research through the lens of an anthropology of knowledge", In Forum Qualitative Sozialforschung/Forum: Qualitative Social Research, Vol. 10 No. 1. 
Knight, E. and Harvey, W.S. (2015), "Managing exploration and exploitation in creative organizations", Management Decision, Vol. 53 No. 4, pp. 809-827.

Krylova, K.O., Vera, D. and Crossan, M. (2016), "Knowledge transfer in knowledge-intensive organizations: the crucial role of improvisation in transferring and protecting knowledge", Journal of Knowledge Management, Vol. 20 No. 5, pp. 1045-1064.

Kuhn, T. (2012), "Negotiating the micro-macro divide: thought leadership from organizational communication for theorizing organization", Management Communication Quarterly, Vol. 26, No. 4, pp. 543-584.

Kurtman, K. (1998), Thought Leaders: Insights on the Future of Business. Booz Allen and Hamilton Inc, San Francisco, CA.

Kwon, K. and Cho, D. (2016), "How transactive memory systems relate to organizational innovation: the mediating role of developmental leadership", Journal of Knowledge Management, Vol. 20 No. 5, pp. 1025-1044.

Lam, A. (2000), "Tacit knowledge, organizational learning and societal institutions: an integrated framework", Organization Studies, Vol. 21 No. 3, pp. 487-513.

Lange, D., Lee, P.M. and Dai, Y. (2011), "Organizational reputation: a review", Journal of Management, Vol. 37 No. 1, pp. 153-184.

Le, P.B. and Lei, H. (2019), "Determinants of innovation capability: the roles of transformational leadership, knowledge sharing and perceived organizational support", Journal of Knowledge Management, Vol. 23 No. 3, pp. 527-547.

Leavitt, R., Baxter Perrin, A. and France, N. (2016), "Engaging customers in thought leadership development", ITSMA 2016, available at: www.itsma.com/research/engaging-customers-thoughtleadership-development/ (accessed 19 April 2019).

Levy, M. (2014), "5 best practice of thought leadership", available at: www.socialbuzzclub.com/5-bestpractices-thought-leadership/ (accessed 26 August 2020).

Lewis M.W. (2000), "Exploring paradox: toward a more comprehensive guide", Academy of Management Review, Vol. 25 No. 4, pp. 760-776.

Lewis, M.W., Andriopoulos, C. and Smith, W.K. (2014), "Paradoxical leadership to enable strategic agility", California Management Review, Vol. 56 No. 3, pp. 58-77.

Lichtenthaler, U. and Ernst, U. (2009), "Opening up the innovation process: the role of technology aggressiveness", R\&D Management, Vol. 39 No. 1, pp. 38-54.

Lin, N. (2001), Social Capital: A Theory of Social Structure and Action. Cambridge University Press, Cambridge.

Lin, N., Cook, K.S. and Burt, R.S. (Eds) (2001), Social Capital: Theory and research. Transaction Publishers, New Brunswick, New Jersey.

Little, T.A. and Deokar, A.V. (2016), "Understanding knowledge creation in the context of knowledge-intensive business processes", Journal of Knowledge Management, Vol. 20 No. 5, pp. 858-879.

Lowik, S., Kraaijenbrink, J. and Groen, A. (2016), "The team absorptive capacity triad: a configurational study of individual, enabling, and motivating factors”, Journal of Knowledge Management, Vol. 20 No. 5 , pp. 1083-1103.

Lundvall, B.-^̊. (1988), "Innovation as an interactive process: from user-producer interaction to the national system of innovation", in Dosi, G., Freeman, C., Silverberg, G., and Soete, L. (Eds), Technical Change and Economic Theory, Pinter, London, pp. 349-369.

Luscher, L.S. and Lewis, M.W. (2008), "Organizational change and managerial sensemaking: working through paradox", Academy of Management Journal, Vol. 51 No. 2, pp. 221-240.

McCrimmon, M. (2005), "Thought Leadership: a radical departure from traditional, positional leadership", Management Decision, Vol. 43 Nos 7/8, pp. 1064-1070.

McKeon, P. (2009). "Is anybody following your thought leadership? Five best-practices", available at: www.6pmarketing.com/articles/branding-science/72-marketing-strategy/140-is-anybodyfollowing-yourthought-leadership-five-best-practices (accessed 26 August 2020). 
Maak, T. (2007). "Responsible leadership, stakeholder engagement, and the emergence of social capital", Journal of Business Ethics, Vol. 74 No. 4, 329-343.

Maak, T. and Pless, N.M. (2006), "Responsible leadership in a stakeholder society - a relational perspective", Journal of Business Ethics, Vol. 66 No. 1, pp. 99-115.

Magno, F. and Cassia, F. (2019), "Establishing thought leadership through social media in B2B settings: effects on customer relationship performance", Journal of Business \& Industrial Marketing, Vol. 35 No. 3 , pp. 437-446.

Malhotra, N. and Morris, T. (2009), "Heterogeneity in professional service firms", Journal of Management Studies, Vol. 46 No. 6, pp. 895-922.

Manbitesdog (2014), "Follow the leader. Where next for thought leadership in professional services?", available at: www.manbitesdog.com/wp-content/uploads/2014/03/Follow-The-Leader-Full-Report.pdf (accessed 26 August 2020).

Maskell, P. and Malmberg, A. (1999), "Localised learning and industrial competitiveness", Cambridge Journal of Economics, Vol. 23 No. 2, pp. 167-185.

Marchant, G. and Robinson, J. (1999), "Is knowing the tax code all it takes to be a tax expert? On the development of legal expertise", Tacit knowledge in Professional Practice, pp. 3-20.

Marin, A., Cordier, J. and Hameed, T. (2016), "Reconciling ambiguity with interaction: implementing formal knowledge strategies in a knowledge-intensive organization", Journal of Knowledge Management, Vol. 20 No. 5, pp. 959-979.

Millar, C.C., Lockett, M. and Mahon, J.F. (2016), "Guest editorial: knowledge intensive organisations: on the frontiers of knowledge management", Journal of Knowledge Management, Vol. 20, No. 5, pp. 845-857.

Miles, I. (2008), "Patterns of innovation in service industries", IBM Systems journal, Vol. 47 No. 1, pp. 115-128.

Miles, M.B. and Huberman, A.M. (1994), Qualitative Data Analysis (2nd Edition), SAGE Publications Inc., Thousand Oaks, CA.

Mitchell, V.W. (1994), "Using industrial key informants: some guidelines", Market Research Society Journal, Vol. 36 No. 2, pp. 1-5.

Mitchell, V.W. (1995), "Organisational risk perception and reduction: a literature review", British Journal of Management, Vol. 6 No. 2, pp. 115-133.

Mitchell, V.W., Moutinho, L. and Lewis, B.R. (2003), "Risk reduction in purchasing organisational professional services", The Service Industries Journal, Vol. 23No. 5, pp. 1-19.

Murphy, K.R. and Saal, F.E. (1990), "What should we expect from scientist-practitioners", Psychology in Organizations: Integrating Science and Practice, pp. 49-66.

Nelson, R.R. and Winter, S.G. (1982), "The Schumpeterian tradeoff revisited", The American Economic Review, Vol. 72 No. 1, pp. 114-132.

Nguyen, T.M., Nham, T.P., Froese, F.J. and Malik, A. (2019), "Motivation and knowledge sharing: a metaanalysis of main and moderating effects", Journal of Knowledge Management, Vol. 23 No. 5, pp. 998-1016.

Nonaka, I. and Takeuchi, H. (1995), The Knowledge-Creating Company: How Japanese Companies Create the Dynamics of Innovation, Oxford University Press.

Orbit Media Studios (2020), "What is thought leadership marketing? A new definition for marketers based on research", available at:www.orbitmedia.com/blog/what-is-thought-leadership-marketing/ (accessed 26 August 2020).

Pearce, C.L. (2004), "The future of leadership: combining vertical and shared leadership to transform knowledge work”, Academy of Management Executive, Vol. 18 No. 1, pp. 47-57.

Pearce, T. (2013), "Leading out loud: a guide for engaging others in creating the future", John Wiley and Sons, Vol. 393.

Polanyi, M. (1966), “The logic of tacit inference”, Philosophy, Vol. 41 No. 155, pp. 1-18.

Pollock, T.G., Lashley, K., Rindova, V.P. and Han, J.H. (2019), "Which of these things are not like the others? Comparing the rational, emotional, and moral aspects of reputation, status, celebrity, and stigma", Academy of Management Annals, Vol. 13 No. 2, pp. 444-478. 
Press, E. and Washburn, J. (2000), "The kept university", Atlantic Monthly, Vol. 285 No. 3.

Prince, R.A. and Rogers, B. (2012), "What is a thought leader?", Forbes, available at: www.forbes.com/ sites/russprince/2012/03/16/what-is-a-thought-leader/

Putnam, R.D. (2000), Bowling Alone: The collapse and revival of American community. Simon \& Schuster, New York.

Rasmus, D.W. (2012), "The golden rules for creating thoughtful thought leadership", Fast Company, available at: www.fastcompany.com/3003897/golden-rules-creating-thoughtfulthought-leadership

Ravasi, D., Rindova, V., Etter, M. and Cornelissen, J. (2018), "The formation of organizational reputation", Academy of Management Annals, Vol. 12 No. 2, pp. 574-599.

Rindova, V.P., Williamson, I.O., Petkova, A.P. and Sever, J.M. (2005), "Being good or being known: an empirical examination of the dimensions, antecedents, and consequences of organizational reputation", Academy of Management Journal, Vol. 48 No. 6, pp. 1033-1049.

Rogers, E.M. and Cartano, D.G. (1962), "Methods of measuring opinion leadership", Public Opinion Quarterly, Vol. 26 No. 3, pp. 435-441.

Rohajawati, S., Sensuse, D.I., Sucahyo, Y.G. and Arymurthy, A.M. (2016), "Mental health knowledge management: critical success factors and strategy of implementation", Journal of Knowledge Management, Vol. 20 No. 5, pp. 980-1003.

Sarstedt, M., Wilczynski, P. and Melewar, T.C. (2013), "Measuring reputation in global markets - a comparison of reputation measures' convergent and criterion validities", Journal of World Business, Vol. 48 No. 3, pp. 329-339.

Schad, J., Lewis, M.W., Raisch, S. and Smith, W.K. (2016), "Paradox research in management science: looking back to move forward", Academy of Management Annals, Vol. 10 No. 1, pp. 5-64.

Smith, W.K. and Lewis, M.W. (2011), "Toward a theory of paradox: a dynamic equilibrium model of organizing", Academy of Management Review, Vol. 36 No. 2, pp. 381-403.

Spence, M. (1973), "Job Market Signaling", Quarterly Journal of Economics Vol. 87 No. 3, pp. 355-374.

Spicer, A. (2017), "From inboxing to thought showers: how business bullshit took over", The Guardian, available at: www.theguardian.com/news/2017/nov/23/from-inboxing-to-thought-showers-how-businessbullshit-took-over (accessed 26 August 2020).

Stewart, F.A. (1947), "A sociometric study of influence in Southtown", Sociometry, Vol. 10 No. 1, pp. 11-31.

Suddaby, R. (2006), "From the editors: what grounded theory is not", Academy of Management Journal, Vol. 49 No. 4, pp. 633-642.

Sudhir, K. (2016), "The exploration-exploitation tradeoff and efficiency in knowledge production", Marketing Science, Vol. 35 No. 1, pp. 1-9.

Tech Target (2018), "Thought leader (thought leadership)", available at: https://searchcio.techtarget. com/definition/thought-leader (accessed 26 August 2020).

Uhl-Bien, M. (2006), "Relational leadership theory: exploring the social processes of leadership and organizing", Leadership Quarterly, Vol. 17 No. 6, pp. 654-676.

van Wijk, J., Zietsma, C., Dorado, S., de Bakker, F.G. and Martí, I. (2019), "Social innovation: integrating micro, Meso, and Macro level insights from institutional theory", Business \& Society, Vol. 58 No. 5 , pp. 887-918.

Velamuri, R.S., Venkataraman, S. and Harvey, W.S. (2017), "Seizing the ethical high ground: ethical reputation building in corrupt environments", Journal of Management Studies, Vol. 54 No. 5 , pp. 647-675.

Vendrell-Herrero, F., Darko, C.K. and Ghauri, P. (2019), "Knowledge management competences, exporting and productivity: uncovering African paradoxes", Journal of Knowledge Management, Vol. 24 No. 1, pp. 81-104.

Von Nordenflycht, A. (2010), "What is a professional service firm? Toward a theory and taxonomy of knowledge-intensive firms", Academy of Management Review, Vol. 35 No. 1, pp. 155-174. 
West, J., Salter, A., Vanhaverbeke, W. and Chesbrough, H. (2014), "Open innovation: the next decade", Research Policy, Vol. 43 No. 5, pp. 805-811.

Wittlake, E. (2015), "The best way to measure thought leadership", available at: https://businessesgrow. com/2015/05/07/measure-thought-leadership/ (accessed 26 August 2020).

Wong, G., Greenhalgh, T., Westhorp, G., Buckingham, J. and Pawson, R. (2013), RAMESES publication standards: meta-narrative reviews. BMC Medicine, Vol. 11 No. 1, pp. 20.

Wright, C. (2019), "Thought leaders and followers", in Sturdy, A., Heusinkveld, S., Reay, T. and Strang, D. (Eds), The Oxford Handbook of Management Ideas, Oxford University Press, Oxford, pp. 140-158.

Wu, I.L. and Hu, Y.P. (2018), "Open innovation based knowledge management implementation: a mediating role of knowledge management design", Journal of Knowledge Management, Vol. 22 No. 8, pp. 1736-1756.

Young, L. (2013), "Thought leadership: prompting businesses to think and learn", Kogan Page Publishers.

Zalewska-Kurek, K. (2016), “Understanding researchers' strategic behaviour in knowledge production: a case of social science and nanotechnology researchers", Journal of Knowledge Management, Vol. 20 No. 5, pp. 1148-1167.

Zhang, Y. and Han, Y.L. (2019), "Paradoxical leader behavior in long-term corporate development: antecedents and consequences", Organizational Behavior and Human Decision Processes, Vol. 155, pp. 42-54.

\section{Further reading}

Coleman, J.S. (1988), "Social capital in the creation of human capital", American Journal of Sociology, 94, pp. S95-S120.

Czerniawska, F. and Haigh, E. (2014), "Thought leadership. Understanding the impact of thought leadership", available at: www.sourceforconsulting.com/blog/2014/09/21/understanding-the-impact-ofthought-leadership/\#comments (accessed 26 August 2020).

Denford, J.S. (2013), "Building knowledge: developing a knowledge-based dynamic capabilities typology", Journal of Knowledge Management, Vol. 17 No. 2, pp. 175-194.

Greenhalgh, T., Robert, G., Macfarlane, F., BATE, P. and Kyriakidou, O. (2004), "Diffusion of innovations in service organizations: systematic review and recommendations", Milbank Quarterly, Vol. 82, pp. 581-629.

Klein, K.J. and Kozlowski, S.W. (2000), "From micro to meso: critical steps in conceptualizing and conducting multilevel research", Organizational Research Methods, Vol. 3 No. 3, pp. 211-236.

Maister, D.H. (1993), Managing the Professional Service Firm, Simon and Schuster, New York.

Phillips, J. (2006), The Art of Original Thinking: The Making of a Thought Leader. 9th Element Press. San Diego.

Raath, A. (2006), Thought Leadership: Resistance is Futile, Unpublished MBA Dissertation, Cass Business School, City University.

Rao, A., Spasojevic, N., Li, Z. and Dsouza, T. (2015), "Klout score: measuring influence across multiple social networks", In 2015 IEEE International Conference on Big Data, pp. 2282-2289.

Reichheld, F.F. (2003), "The one number you need to grow", Harvard Business Review, Vol. 81 No. 12, pp. 46-55.

Rogers, E.M. (1976), "New product adoption and diffusion”, Journal of Consumer Research, Vol. 2 No. 4, pp. 290-301.

Rogers, E.M. (1995), Diffusion of Innovations, Free Press, New York.

Scouller, J. (2011), The Three Levels of Leadership: How to Develop Your Leadership Presence, Knowhow and Skill, Management Books, Cirencester.

The Economist (2010), "Consultancy firms. Free thinking", available at: www.economist.com/node/ 16994439 (accessed 26 August 2020). 
The Economist (2013), "Consultancy firms. Strategic moves", available at: www.economist.com/ news/business/21589435-big-consulting-and-accounting-firms-are-making-risky-move-strategywork-strategic-moves (accessed 26 August 2020).

Zack, M.H. (2003), "Rethinking the knowledge-based organization", MIT Sloan Management Review, Vol. 44 No. 4, pp. 67-72.

\section{Corresponding author}

William S. Harvey can be contacted at: william.harvey@exeter.ac.uk

For instructions on how to order reprints of this article, please visit our website: www.emeraldgrouppublishing.com/licensing/reprints.htm

Or contact us for further details: permissions@emeraldinsight.com 